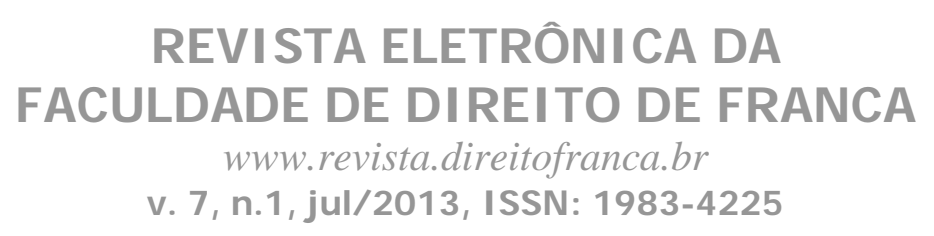

\title{
OS IMPACTOS DA GLOBALIZAÇÃO ECONÔMICA SOBRE A SOBERANIA
}

\author{
Marlon Tomazette \\ http://buscatextual.cnpq.br/buscatextual/visualizacv.do?id=K4137541J6
}

\begin{abstract}
Resumo: A globalização econômica impacta os modos de produção do direito, a concepção e as funções clássicas do Estado bem como a concepção tradicional de soberania. Na realidade de uma interdependência global não são mais sustentáveis concepções isoladas dos Estados, os quais devem se inserir na realidade global participando de entidades de caráter internacional como a OMC e o MERCOSUL e supranacional, como a União Europeia. A inserção nessa realidade bem como as exigências da atual economia impõem uma reconfiguração da soberania, de modo que se chegue a um compartilhamento ao menos parcial de competências para atuação no cenário global. Nesta perspectiva, a soberania enquanto poder absoluto e indivisível não é mais possível, devendo-se reconfigurar esse conceito, sem abandonar o Estado Nacional.
\end{abstract}

Palavras-chave: Globalização econômica, Estado Nacional, soberania.

\section{The impacts of economic globalization over sovereignty}

Abstract: Economic globalization impacts the production modes of law, the conception and the classic functions of the state as well as the traditional conception of sovereignty. In the reality of global interdependence, concepts of isolated states are not sustainable anymore. States must insert themselves in the global reality participating in international entities such as like the WTO and Mercosul and the supranational entities, as the European Union. The insertion in this reality and the requirements of the current economy imposes a reconfiguration of sovereignty, so that we reach an at least partial sharing of competences to act on the global scenario. In this perspective, sovereignty as an indivisible and absolute power is no longer possible, it is necessary to reconfigure the concept, without abandoning the Nation State.

Keywords: economic globalization, State, sovereignty.

\section{INTRODUÇÃO}

A globalização econômica, embora não seja um fenômeno novo, torna-se atualmente ainda mais influente, na medida em que impacta as concepções tradicionais da produção normativa, do Estado Nacional e da soberania enquanto atributo clássico do Estado. Nenhum desses fenômenos está livre das influências dessa nova realidade que se apresenta no atual configuração mundial, na qual as fronteiras estão cada vez menos definidas e muita coisa já é realizada em escala global. Concepções tradicionais devem ser superadas ou ao menos reconfiguradas para se adequarem a essa realidade. A globalização gera o fim da soberania ou apenas a sua reconfiguração? O Estado soberano está fadado à extinção ou ainda sobreviverá na 


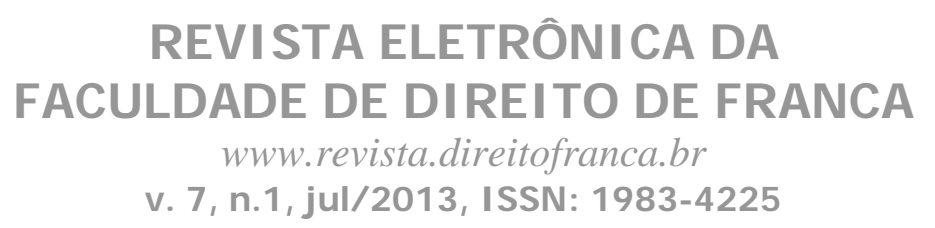

atual sociedade global? O presente estudo visa justamente a analisar o futuro da soberania, diante dos impactos gerados pela globalização econômica.

Para entender essas mudanças, é essencial analisar inicialmente a formação dos Estados nacionais modernos e seus atributos clássicos, uma vez que foi nesse cenário que se construiu a concepção clássica da soberania ora discutida. Além disso, é essencial mostrar que esse Estado nacional moderno se depara atualmente com o surgimento de mudanças radicais na sociedade causadas pelo fenômeno da globalização, em especial a globalização econômica. Este fenômeno que impacta a sociedade impacta também a própria ideia do Estado nacional que, por conseguinte, deve sofrer mudanças para se adequar a essa nova realidade.

Dentre essas mudanças, surgem mudanças que também vão afetar diretamente a concepção tradicional do Direito, sendo possível apontar diversas tendências, dentre as quais merece especial destaque a mudança do conteúdo e no sistema de produção das normas. Com a globalização econômica, o Estado já não tem mais a capacidade de lidar sozinho com todas estas

tarefas. Muitas relações jurídicas já não são travadas dentro de limites territoriais que sempre pautaram a atuação do Estado. Há a necessidade de uma internacionalização do direito que poderá se operar de diversas formas. Diante dessa situação, impõe-se o surgimento de novos atores que assumirão o papel de protagonistas inclusive na produção normativa.

Diante de tudo isso, resta analisar o que ocorrerá com a soberania diante dessa nova realidade econômica, isto é, deve-se analisar o futuro desse conceito. Dentro da mesma ideia, serão apresentados a concepção e os atributos clássicos da soberania, fim de saber como a soberania deve se comportar na atual realidade, em que o Brasil se insere na realidade global como membro da Organização Mundial do Comércio e do MERCOSUL.

\section{O SURGIMENTO DOS ESTADOS NACIONAIS}

O estudo da soberania passa necessariamente pelaanálise do Estado, cuja análise pode ser feita desde a antiguidade, passando pelos romanos, gregos e pela civilização medieval. Todavia, para o estudo específico da soberania, o que realmente interessa é o Estado Nacional moderno, pois foi a partir dessa concepção que todo o estudo da soberania se desenvolveu. A disputa entre outros poderes e o Estado moderno que surgia foi fundamental para o desenvolvimento de uma 


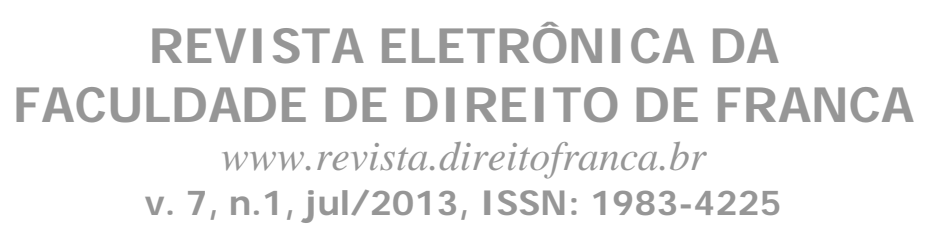

teoria da soberania ${ }^{1}$. "A questão da soberania está direcionada ao poder de imposição do poder público"² naquela sociedade que surgia. A ideia fundamental era a necessidade de "um poder de decisão e de coordenação que encontra sua justificação na regra de vida da comunidade” ${ }^{3}$ que então surgia.

Embora não se negue que a ideia de Estado seja bem anterior ${ }^{4}$, é certo que para os fins do presente trabalho será analisado apenas o Estado Nacional moderno, cujo nascimento é resultado de um "longo e complexo processo de integração e discriminação, no qual interfere uma série de fatores" ${ }^{5}$.Dentro desses diversos fatores, devemos destacar os problemas da sociedade medieval.A queda do império romano e, consequentemente, a ausência de um poder estatal centralizado fizeram surgir pequenas cidades, as quais se mantiveram fechadas durante toda a idade média ${ }^{6}$.

No fim da idade média, por volta dos séculos XI e XII, com a reabertura das vias comerciais do norte e do sul da Europa, desenvolve-se uma mudança radical na configuração da sociedade, há uma grande imigração do campo, formando-se cidades como centros de consumo, de troca e de produção industrial. Essa mudança foi provocada pela crise do sistema feudal, resultado da subutilização dos recursos do solo, da baixa produtividade do trabalho servil, aliadas ao aumento da pressão exercida pelos senhores feudais sobre a população.

Com o crescimento demográfico nas cidades e o consequente excesso de oferta de mãode-obra, houve um aumento na produção que desenvolveu as cidades e o comércio internacional, mobilizando grandes capitais. Neste momento, a burguesia ascendente se associa a nobreza e forma os chamados estados absolutistas, ainda não desvinculados completamente da Igreja, mas já havendo um grande declínio do poder desta, em função de um início da separação entre o poder político e poder secular, fortemente influenciado pela reforma protestante.

\footnotetext{
${ }^{1}$ FLEINER-GESTER, Tomas. Teoria geral do Estado. Tradução de Marlene Holzhausen. São Paulo: Martins Fontes, 2006, p. 218; STRECK, Lênio Luiz; MORAIS, José Luiz Bolzan de. Ciência política e teoria do Estado. 6. Ed. Porto Alegre: Livraria do advogado, 2008, p. 167.

${ }^{2}$ KRIELE, Martin. Introdução à teoria do Estado: os fundamentos históricos da legitimidade do Estado Constitucional Democrático. Tradução de Urbano Carvelli. Porto Alegre: Sergio Antonio Fabris, 2008, p. 29.

${ }^{3}$ BURDEAU, Georges. O Estado. Tradução de Maria Ermantina de Almeida Prado Galvão. São Paulo: Martins Fontes, 2005, p. 34.

${ }^{4}$ DALLARI, Dalmo de Abreu. Teoria geral do Estado. 30. Ed. São Paulo: Saraiva, 2011, p. 78

${ }^{5}$ REALE, Miguel. Teoria do Direito e do Estado. 5. Ed. São Paulo: Saraiva, 2000, p. 41.

${ }^{6}$ GALGANO, Francesco. História do Direito comercial. Tradução de João Espírito Santo. Lisboa: PF, 1990, p. 31; DE LEO, Walter N. Derecho de los negocios en el comercio. Buenos Aires: Universidad, 1999, p. 35.
} 


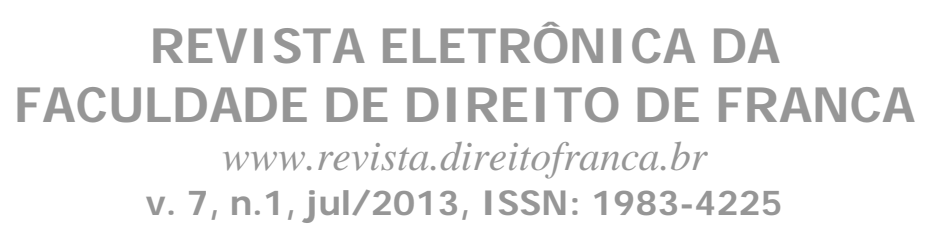

Vale ressaltar que nos Estados absolutistas é retomada a ideia de unidade do Estado, que era fundamental nos Estados da antiguidade ${ }^{7}$. Esse Estado absolutista necessitava de grandes quantidades de capitais para se desenvolver, o que só foi possível em função do modo de produção adotado. "O mercantilismo implicava uma política estatal de nacionalismo econômico e girava em torno de uma preocupação com a circulação de mercadorias, quer em termos do movimento de metais preciosos, quer em termos da criação de equilíbrios comerciais”8 ${ }^{\text {. }}$

A formação do Estado moderno que se inicia nesse período se conclui com transformações que ocorrem dentro do próprio Estado em consequência de movimentos revolucionários, especialmente na França, na Inglaterra e nos Estados Unidos durante os séculos XVII e XVIII ${ }^{9}$, formando o que se convencionou denominar de Estados Nacionais ou Estado Nação. Os tratados de paz de Westfália representaram a documentação histórica do surgimento desse novo tipo de Estado, caracterizado basicamente pela ideia de uma "unidade territorial, dotada de um poder soberano” ${ }^{10}$ e pelo reconhecimento recíproco dos Estados ${ }^{11}$. A consciência nacional se transforma numa poderosa força de mobilização, de coesão e de afirmação social.

\section{OS ELEMENTOS DO ESTADO NACIONAL}

Partindo dessa ideia geral, podem ser explicados os elementos essenciais dessa concepção de Estado. Alguns autores apresentam três elementos essenciais para o Estado: povo, território e soberania $^{12}$. Outros apresentam como elementos a população, o território e o governo ${ }^{13}$. De outro

\footnotetext{
${ }^{7}$ JELLINEK, Georg. TeoriaGeneral del Estado. Traducción por Fernando de Los Rios Urruti. Granada: Comares, 2000, p. 320.

${ }^{8}$ WALLERSTEIN, Immanuel. O sistema mundial moderno. São Paulo: Afrontamento, 1994, v. II, p. 46.

${ }^{9}$ JELLINEK, Georg. TeoriaGeneral del Estado. Traducción por Fernando de Los Rios Urruti. Granada: Comares, 2000, p. 320.

${ }^{10}$ DALLARI, Dalmo de Abreu. Teoria geral do Estado. 30. Ed. São Paulo: Saraiva, 2011, p. 78.

${ }^{11}$ ELCIN, Mert. The applicable Law to international commercial contracts and status of lex mercatoria. Boca Raton: Dissertation.com, 2010, p. 9; KRASNER, Stephen. D. Sovereignty: organized hypocrisy. Princeton: Princeton University Press, 1999, p. 81.

${ }^{12}$ FLEINER-GESTER, Tomas. Teoria geral do Estado. Tradução de Marlene Holzhausen. São Paulo: Martins Fontes, 2006, p. 183; SOARES, Mário Lúcio Quintão. Teoria do Estado: novos paradigmas em face da globalização. 3. Ed. São Paulo: Atlas, 2008, p. 88; STRECK, Lênio Luiz; MORAIS, José Luiz Bolzan de. Ciência política e teoria do Estado. 6. Ed. Porto Alegre: Livraria do advogado, 2008, p. 163.

${ }^{13}$ AZAMBUJA, Darcy. Teoria geral do Estado. 4. Ed. São Paulo: Globo, 2008, p. 34; CALMON, Pedro. Curso de Teoria Geral do Estado. Rio de Janeiro: Freitas Bastos, 1958, p. 124; FERREIRA, Pinto. Teoria geral do Estado. 3.
} 


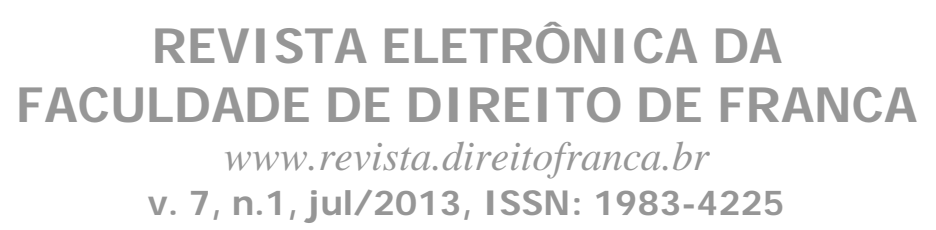

lado, há quem identifique cinco elementos no conceito de Estado: população, território, governo soberano, ordenamento jurídico e bem como comum (finalidade) ${ }^{14}$. Outros identificam quatro elementos: um território, um elemento pessoal, um governo e a soberania ${ }^{15}$. Apesar dessas divergências, a última forma de organização da matéria será a utilizada, estudando os quatro elementos do Estado.

\subsection{O TERRITÓRIO}

A natureza desse elemento é extremamente discutível, havendo inclusive quem negue sua essencialidade para a ideia de Estado, sendo opinião amplamente majoritária a que reconhece o território como elemento essencial do Estado ${ }^{16}$. Reconhecendo essa essencialidade, Paulo Bonavides ${ }^{17}$ divide as teorias sobre a natureza do território assim: a Teoria do TerritórioPatrimônio, a Teoria do Território-Objeto, a Teoria do Território-Espaço e a Teoria do Território Competência. Há quem mencione ainda uma quinta teoria, a teoria do território-limite ${ }^{18}$.

A primeira teoria analisa o território de forma privatista, isto é, "era o poder do Estado sobre o território da mesma natureza do direito do proprietário sobre o imóvel” ${ }^{19}$.Essa concepção foi diretamente influenciada pela sociedade política medieval e pelo sistema feudal, sem distinções claras entre a propriedade o poder de império atribuído ao Estado. Todavia, ela não

Ed. São Paulo: Saraiva, 1975, v. 1, p. 101; MALUF, Sahid. Teoria geral do Estado. 26. Ed. São Paulo: Saraiva, 2003, p. 23.

${ }^{14}$ FILOMENO, José Geraldo. Manual de teoria geral do Estado. 7. Ed. Rio de Janeiro: Forense universitária, 2009, p. 68.

${ }^{15}$ DAILLIER, Patrick; FORTEAU, Mathias; PELLET, Allain. Droit international public. 8. Ed. Paris: LGDJ, 2009, p. 450; VARELLA, Marcelo D. Direito internacional público. São Paulo: Saraiva, 2009, p. 149; MENEZES, Aderson. Teoria Geral do Estado. 2. Ed. Rio de Janeiro: Forense, 1967, p. 129.

${ }^{16}$ VARELLA, Marcelo D. Direito internacional público. São Paulo: Saraiva, 2009, p. 189; DAILLIER, Patrick; FORTEAU, Mathias; PELLET, Allain. Droit international public. 8. Ed. Paris: LGDJ, 2009, p. 454; CASSESE, Antonio. International law. 2. Ed. Oxford: Oxford, 2005, p. 82; DALLARI, Dalmo de Abreu. Teoria geral do Estado. 30. Ed. São Paulo: Saraiva, 2011, p. 95; SHAW, Malcom N. International law. 6. Ed. Cambridge: Cambridge, 2008, p. 199; BROWNLIE, Ian. Principles of international law. 7. Ed. Oxford: Oxford, 2008, p. 105; FILOMENO, José Geraldo. Manual de teoria geral do Estado. 7. Ed. Rio de Janeiro: Forense universitária, 2009, p. 76; AZAMBUJA, Darcy. Teoria geral do Estado. 4. Ed. São Paulo: Globo, 2008, p. 54.

${ }^{17}$ BONAVIDES, Paulo. Ciência política. 10. Ed. São Paulo: Malheiros, 1994, p. 98.

${ }^{18}$ SOARES, Mário Lúcio Quintão. Teoria do Estado: novos paradigmas em face da globalização. 3. Ed. São Paulo: Atlas, 2008, p. 128.

${ }^{19}$ BONAVIDES, Paulo. Ciência política. 10. Ed. São Paulo: Malheiros, 1994, p. 100. 


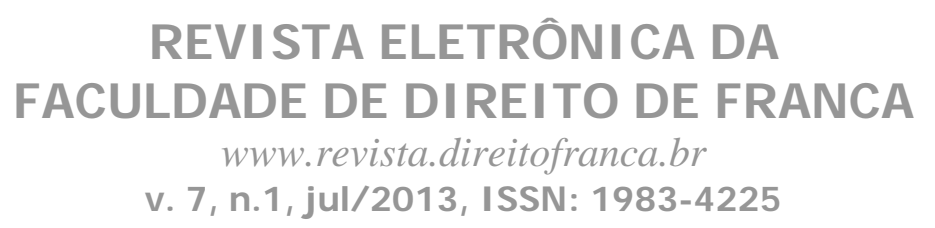

pode ser aceita hoje em dia. Se tal teoria estivesse correta, todas as terras de um país seriam terras públicas ${ }^{20}$ e, como é sabido, a propriedade é reconhecida em quase todo o mundo.

A segunda teoria nunca conseguiu se desprender completamente da primeira, analisando o território com "um objeto de um direito das coisas público ou de um direito real de caráter público”21. Torna-se o território um objeto de direito, não de um direito privado, mas de um direito público. Como já ressaltado, as variações são pequenas em relação àquela concepção anterior.

A terceira teoria entende que o território seria o espaço do Estado, isto é, não haveria um direito do Estado sobre o território, isto é, “o poder do Estado não é poder sobre o território, mas poder no território e qualquer modificação do território do Estado implica a modificação mesma do Estado”22. Destaca-se, nesta concepção o território enquanto delimitação espacial do poder e não como objeto de direito de direito.

De outro lado, a teoria do Estado competência reflete a concepção kelseniana do território enquanto âmbito de validade da ordem jurídica do Estado, isto é, a atuação jurídica do Estado só poderia ocorrer dentro dos limites do seu território ${ }^{23}$. Trata-se de concepção ainda hoje em dia bastante aceita ${ }^{24}$, apesar das críticas comumente feitas ao pensamento de Kelsen. Por fim, há que se mencionar ainda a teoria do território limite, pela qual este elemento representaria "o limite material da ação efetiva dos governantes, configurando-se como limite da validade dos atos emanados do Estado"25.

Portanto, o território representa o domínio espacial do Estado, isto é,“a porção de terra sujeita à autoridade soberana do Estado”26, isto é, “o espaço onde se aplica o poder do Estado”27. Embora essa concepção possa parecer limitadora, é certo que foi a definição do território que

\footnotetext{
${ }^{20}$ VARELLA, Marcelo D. Direito internacional público. São Paulo: Saraiva, 2009, p. 189.

${ }^{21}$ BONAVIDES, Paulo. Ciência política. 10. Ed. São Paulo: Malheiros, 1994, p. 101.

${ }^{22}$ BONAVIDES, Paulo. Ciência política. 10. Ed. São Paulo: Malheiros, 1994, p. 105.

${ }^{23}$ KELSEN, Hans. Teoria geral do direito e do Estado. 2. Ed. São Paulo: Martins Fontes, 1992, p. 207.

${ }^{24}$ VARELLA, Marcelo D. Direito internacional público. São Paulo: Saraiva, 2009, p. 189.

${ }^{25}$ SOARES, Mário Lúcio Quintão. Teoria do Estado: novos paradigmas em face da globalização. 3. Ed. São Paulo: Atlas, 2008, p. 128.

${ }^{26}$ CASSESE, Antonio. International law. 2. Ed. Oxford: Oxford, 2005, p. 82, tradução livre de "the portion of land subject to a sovereign power".

${ }^{27}$ DAILLIER, Patrick; FORTEAU, Mathias; PELLET, Allain. Droit international public. 8. Ed. Paris: LGDJ, 2009, p. 457, tradução livre de “l'espace où s’applique le pouvoir de l'État”.
} 


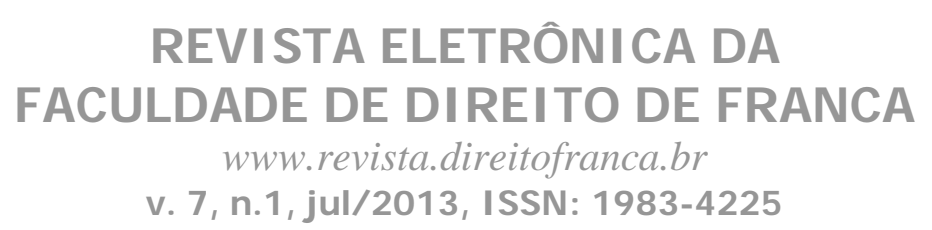

permitiu a consolidação dos limites físicos e fáticos da atuação do Estado. Sem essa delimitação, não seria possível a consolidação dessa concepção de Estado.

\subsection{ELEMENTO PESSOAL DO ESTADO}

Além do aspecto espacial já destacado, o Estado Nacional se caracteriza também por um elemento pessoal, um conjunto de pessoas. Há, porém divergências terminológicas na qualificação desse elemento, chamado de população para alguns e de povo para outros.

Para Marcelo Varella, a "população é o conjunto de habitantes que mantém uma ligação com um determinado Estado, por de um vínculo jurídico, o vínculo da nacionalidade”28. Essa ideia abrange tanto os residentes no Estado como os residentes fora do Estado, desde que presente o vínculo da nacionalidade. Para ele, a ideia de povo envolve um conceito sociológico, sendo a ideia de nação um conceito mais ideológico. Apesar de reconhecer a importância dada a esses outros conceitos, ele reitera que o elemento mais importante é a população.

De outro lado, Paulo Bonavides afirma que a ideia de povo é que envolveria o vínculo de nacionalidade, ao passo que a população seria simplesmente um dado quantitativo, abrangendo "todas as pessoas presentes no território do Estado, num determinado momento, inclusive estrangeiros e apátridas, fazem parte da população"29. De modo similar, Dalmo de Abreu Dallari qualifica o povo como o elemento essencial do Estado, identificando-o como o conjunto de cidadãos que formam o Estado $^{30}$. Martin Kriele identifica o povo também como o conjunto de cidadãos de um Estado ${ }^{31}$.

\footnotetext{
${ }^{28}$ VARELLA, Marcelo D. Direito internacional público. São Paulo: Saraiva, 2009, p. 150. No mesmo sentido: DAILLIER, Patrick; FORTEAU, Mathias; PELLET, Allain. Droitinternational public. 8. Ed. Paris: LGDJ, 2009, p. 451.

29 BONAVIDES, Paulo. Ciência política. 10. Ed. São Paulo: Malheiros, 1994, p. 57. No mesmo sentido: VERGOTTINI, Giuseppe de. Diritto costituzionale. 2. ed. Padova: Cedam, 2000, p. 85; MENEZES, Aderson. Teoria Geral do Estado. 2. Ed. Rio de Janeiro: Forense, 1967, p. 130; BASTOS, Celso Ribeiro. Teoria do Estado e ciência política. 6. Ed. São Paulo: Celso Bastos, 2004, p. 77; ACQUAVIVA, Marcus Cláudio. Teoria Geral do Estado. São Paulo: Saraiva, 1994, p. 24; SOARES, Mário Lúcio Quintão. Teoria do Estado: novos paradigmas em face da globalização. 3. Ed. São Paulo: Atlas, 2008, p. 143; MENDONÇA, Jacy de Souza. O homem e o Estado. São Paulo: Rideel, 2010, p. 171; FERREIRA, Pinto. Teoria geral do Estado. 3. Ed. São Paulo: Saraiva, 1975, v. 1, p. 103.

${ }^{30}$ DALLARI, Dalmo de Abreu. Teoria geral do Estado. 30. Ed. São Paulo: Saraiva, 2011, p. 104.

31 KRIELE, Martin. Introdução à teoria do Estado: os fundamentos históricos da legitimidade do Estado Constitucional Democrático. Tradução de Urbano Carvelli. Porto Alegre: Sergio Antonio Fabris, 2008, p. 126. No mesmo sentido: FILOMENO, José Geraldo. Manual de teoria geral do Estado. 7. Ed. Rio de Janeiro: Forense universitária, 2009, p. 68; AZAMBUJA, Darcy. Teoria geral do Estado. 4. Ed. São Paulo: Globo, 2008, p. 36.
} 


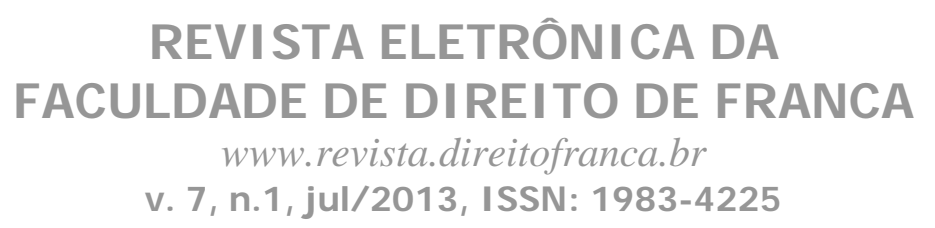

Independentemente de questões terminológico, o fundamental é ressaltar que além do elemento especial (território), a concepção clássica dos Estados nacionais exige um elemento pessoal, um conjunto de pessoas que integre aquele Estado.

\subsection{O GOVERNO}

O terceiro elemento do Estado Nacional na sua concepção clássica é o governo, no sentido de organização posta a serviço do exercício do poder político, ou mais especificamente, “o complexo de órgãos que institucionalmente tem o exercício do poder”32, o "aparelho de mando e coação exercitado pelo Estado” ${ }^{33}$. Trata-se também de elemento essencial, sem o qual não é possível analisar a figura do Estado nacional. Esse elemento exige necessariamente os elementos anteriores, uma que é composto pelo elemento pessoal e terá uma base territorial de atuação.

\subsection{A SOBERANIA}

Por derradeiro, deve-se destacar a soberania como elemento essencial fundante desse conceito de Estado Nacional ${ }^{34}$. Todavia, para fins de organização do trabalho, este elemento será estudado mais adiante, apresentando-se desde a sua concepção clássica, até as atuais perspectivas para esse elemento.

\section{O ESTADO NACIONAL E SUA CONSOLIDAÇÃO}

Definidos os elementos essenciais desse Estado moderno, deve-se analisar sua evolução ao longo do tempo. A partir de 1789 até pelo menos meados do século XX, a ideia clássica do Estado Nacional se consolidou, havendo inclusive quem reconheça durante todo esse período o chamado um ideal de Estado ${ }^{35}$. Para Sabino Cassese, o apogeu do Estado moderno seria

\footnotetext{
32 BOBBIO, Norberto; MATTEUCCI, Nicola; PASQUINO, Gianfranco. Dicionário de política. 5. Ed. Brasília: UnB, 2004, v. 1, p. 553.

${ }^{33}$ MENEZES, Aderson. Teoria Geral do Estado. 2. Ed. Rio de Janeiro: Forense, 1967, p. 139.

${ }^{34}$ SHAW, Malcom N. International law. 6. Ed. Cambridge: Cambridge, 2008, p. 487.

${ }^{35}$ CREVELD, Martin van. Ascensão e declínio do Estado. Tradução de Jussara Simões. São Paulo: Martins Fontes, 2004, p. 269.
} 


\section{REVI STA ELETRÔNI CA DA \\ FACULDADE DE DI REITO DE FRANCA \\ www.revista.direitofranca.br \\ v. 7, n.1, jul/ 2013, I SSN: 1983-4225}

justamente a primeira metade do século $\mathrm{XX}^{36}$. De todo modo, é nesse período que é reconhecida a consolidação dessa figura.

O Estado moderno surgiu com três ideias essenciais: a separação entre a esfera pública e a esfera privada; a dissociação entre o poderio político e o poder econômico; e uma separação entre as funções administrativas e políticas, afastando-se da sociedade civil ${ }^{37}$. Mesmo com mudanças ao longo do tempo, tais elementos se mantiveram e garantiram a condição de protagonista ao Estado que era centrado em dois grandes modelos: o Estado Liberal e o Estado Social. O primeiro surgiu com as revoluções burguesas dos séculos XVIII e XIX e o segundo começou a aparecer no final do século XIX como uma espécie de resposta do Estado às necessidades da sociedade então vigente.

\subsection{O LONGO SÉCULO XIX}

Há certo consenso entre os historiadores de que o século XIX foi longo estendendo-se desde a revolução francesa (1789) até o início da Primeira Guerra Mundial (1914), sendo marcado pela prevalência da filosofia liberal que primava pela não intervenção estatal a não ser naquilo estritamente essencial. Neste particular, o século XIX representou um período de consolidação dessa concepção clássica do Estado.

No longo século XIX, podemos afirmar que houve um longo período de paz, tendo em vista o sucesso da atuação das quatro instituições em que se firmava a civilização desse século, a saber: o sistema de equilíbrio de poder entre as grandes potências, o padrão ouro, o mercado auto regulável e o estado liberal. Tais pilares estão diretamente ligados ao sistema capitalista de produção. Assim, na civilização do século XIX o estado liberal era um dos pilares e representava um estado com poderes e funções limitadas ${ }^{38}$ que permitia ao mercado a sua auto regulação ${ }^{39}$, mas que ainda assim tinha o caráter de protagonista.

\footnotetext{
${ }^{36}$ CASSESE, Sabino. A crise do Estado. Tradução de Ilse Pachoal Moreira e Fernanda Landucci Ortale. Campinas: Saberes, 2010, p. 78.

${ }^{37}$ ROTH, André- Noël. O direito em crise: Fim do Estado moderno? In: FARIA, José Eduardo (org.). Direito $e$ globalização econômica. São Paulo: Malheiros, 1996, p. 16.

${ }_{38}$ BOBBIO, Norberto. Liberalismo e democracia. Tradução de Marco Aurélio Nogueira. São Paulo: Brasiliense, 2005, p. 7.

${ }^{39}$ POLANYI, Karl. A grande transformação. 9. ed. Tradução de Fanny Wrobel. Rio de Janeiro: Elsevier, 2000, p. 17.
} 


\section{REVI STA ELETRÔNI CA DA FACULDADE DE DI REITO DE FRANCA \\ www.revista.direitofranca.br \\ v. 7, n.1, jul/ 2013, I SSN: 1983-4225}

O primeiro pilar era o sistema de equilíbrio de poder que possibilitou a ausência de qualquer guerra duradoura ou devastadora entre as grandes potências ${ }^{40}$. Não se quer afirmar que houve uma paz absoluta, mas apenas ressaltar que os grandes conflitos entre as potências não se realizaram nesse período, permitindo uma maior estabilização do sistema. A Santa aliança conseguiu garantir a paz, com a ajuda de certos instrumentos. Houve uma união de sangue entre os reis e as aristocracias de toda a Europa, que aliada à atuação da Igreja Católica permitia uma condição de governo relativamente estável e eficiente que apena será suplementada pela força para garantir a paz.

O segundo pilar da civilização do século XIX era o padrão ouro, que permitia certa estabilidade na economia internacional evitando desequilíbrios na economia dos países que sempre geravam maiores reflexos. O terceiro pilar da civilização do século XIX foi o mercado auto regulável, pilar este de índole econômica, avesso à intervenção estatal, o qual permitiu um bem-estar material sem precedentes ${ }^{41}$. Tais pilares estão diretamente ligados ao sistema capitalista de produção.

Por fim, a civilização do século XIX tinha por base o estado liberal, uma criação do mercado auto regulável ${ }^{42}$. Por estado liberal deve-se entender um estado com poderes e funções limitadas ${ }^{43}$ que permitia ao mercado a sua auto regulação.

Apesar da paz que pautou o longo século XIX, é certo que esses pilares não se sustentaram e fizeram ruir a civilização do século XIX. O estado liberal, que era uma criação do mercado autoregulável, não conseguiu se sustentar diante do fracasso dessa concepção de auto regulação do mercado que sucumbiu diante da realidade do poder econômico ${ }^{44}$.

Durante o século XIX, o trabalho, a terra e o dinheiro eram livres, isto é, havia muita terra disponível, o abastecimento de mão de obra de baixo padrão fluía livremente e não havia

\footnotetext{
${ }^{40}$ POLANYI, Karl. A grande transformação. 9. ed. Tradução de Fanny Wrobel. Rio de Janeiro: Elsevier, 2000, p. 17.

${ }^{41}$ POLANYI, Karl. A grande transformação. 9. ed. Tradução de Fanny Wrobel. Rio de Janeiro: Elsevier, 2000, p. 17.

${ }^{42}$ POLANYI, Karl. A grande transformação. 9. ed. Tradução de Fanny Wrobel. Rio de Janeiro: Elsevier, 2000, p. 17.

${ }^{43}$ BOBBIO, Norberto. Liberalismo e democracia. Tradução de Marco Aurélio Nogueira. São Paulo: Brasiliense, 2005, p. 7.

${ }^{44}$ GRAU, Eros Roberto. A ordemeconômica na Constituiçãode 1988. 3. ed. São Paulo: Malheiros, 1997, p. 15
} 


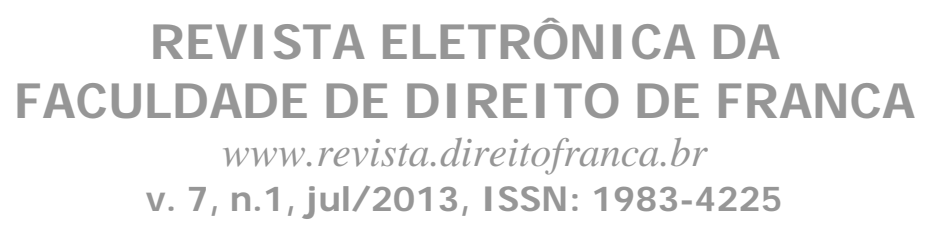

qualquer obrigação de manter as moedas estrangeiras estáveis ${ }^{45}$. Todavia, ao final do século XIX tais condições já não mais existiam e o Estado foi obrigado a tomar medidas protecionistas, intervindo na vida da sociedade de forma mais ampla.

Diante da crise econômica mundial, o sistema de equilíbrio de poder não podia mais se sustentar e sem esse equilíbrio a paz também não tinha como se sustentar. A base da civilização do século XIX era justamente a centralização num mecanismo institucional definido. O padrão ouro mostrou-se crucial e sua queda representou a queda da própria civilização do século XIX ${ }^{46}$, fazendo surgir a civilização do século XX.

\subsection{A EVOLUÇÃO DOS ESTADOS NACIONAIS NO SÉCULO XX}

Já o século XX, sob a perspectiva econômica ${ }^{47}$, é ocupado de modo tenso, pelo conflito entre o sistema capitalista mundial e o sistema socialista então emergente que fez surgir o Estado Social na Europa. De todo modo, nesse período, o Estado pôde influenciar nos âmbitos de produção e da distribuiçãocom o intuito de alcançar crescimento, estabilidade dos preços e pleno emprego, mantendo ainda seu protagonismo. A fisionomia de um século é marcada pelos cortes provocados pelos grandes eventos ${ }^{48}$. É preferível analisar um século pelos eventos ocorridos e não pelas mudanças de tendência e as transformações estruturais. O século XX por sua vez teria sido mais breve, que o século XIX ${ }^{49}$, tendo como marco inicial a Primeira Guerra Mundial (1914) e como marco final, a queda do muro de Berlim e o esfacelamento da UniãoSoviética (1989).

Durante o breve século XX desenvolve-se uma luta de ideias, um antagonismo que perpassa as duas grandes guerras e a Guerra Fria. De acordo com a forma de localizar esse antagonismo, surgem três diferentes interpretações, levando-se o nível econômico dos sistemas sociais, o nível político das grandes potências ou o nível cultural das ideologias.

\footnotetext{
${ }^{45}$ POLANYI, Karl. A grande transformação. 9. ed. Tradução de Fanny Wrobel. Rio de Janeiro: Elsevier, 2000, p. 238.

${ }^{46}$ POLANYI, Karl. A grande transformação. 9. ed. Tradução de Fanny Wrobel. Rio de Janeiro: Elsevier, 2000, p. 17.

${ }^{47}$ HABERMAS, Jürgen. A constelação pós-nacional: ensaios políticos. Tradução de Márcio Seligmann- Silva. São Paulo: Littera Mundi, 2001, p. 59.

${ }^{48}$ HABERMAS, Jürgen. A constelação pós-nacional: ensaios políticos. Tradução de Márcio Seligmann- Silva. São Paulo: Littera Mundi, 2001, p. 58.

${ }^{49}$ Sob a óticaeconômica Giovanni Arrighi faz outraanálise afirmando ser o século XX umséculolongo (1870 até a presentedata) - ARRIGHI, Giovanni. O longoséculo XX. Tradução de VeraRibeiro. Rio de Janeiro: Contraponto, 1996, p. 247 e s.
} 


\section{REVI STA ELETRÔNI CA DA FACULDADE DE DI REITO DE FRANCA \\ www.revista.direitofranca.br \\ v. 7, n.1, jul/ 2013, I SSN: 1983-4225}

Sob a perspectiva econômica ${ }^{50}$, o século XX é ocupado de modo tenso, pelo conflito entre o sistema capitalista mundial e o sistema socialista então emergente. Tal conflito só pôde surgir em virtude da industrialização forçada da União Soviética, que lhe garantiu a condição de potência política, mas nunca garantiu uma base econômica para uma alternativa razoável ou durável para o sistema capitalista.

Sob a perspectiva política ${ }^{51}$, o século XX é marcado pela presença de um totalitarismo que rompe com o processo que teve início no iluminismo. As ideias iluministas são deixadas de lado, em alguns países, dando lugar a uma violência totalitária sem fronteiras, quebrando os limites do direito internacional, do mesmo modo que tal violência, internamente, quebrava as garantias constitucionais.

Sob a perspectiva ideológica, o século XX é marcado por uma cruzada ideológica entre partidos que se não são da mesma categoria, possuem ao menos uma mentalidade semelhante ${ }^{52}$. Ambos os lados antagônicos parecem combaterem "um conflito de visões do mundo entre programas fundamentados na filosofia da história"53.

Embora não se possa negar as diferenças entre as três interpretações, é certo que elas tem um traço em comum, qual seja, analisar os traços terríveis do século XX, quando se inventou uma câmara de gás, uma guerra total, um genocídio feito pelo Estado, uma campo de extermínio, a lavagem cerebral e a vigilância completa de populações inteiras. Todas as interpretações permitem vislumbrar que o século XX gerou mais violência, mais morte, mais guerras e mais conflitos do que pôde imaginar. Habermas crítica essas interpretações, na medida em que as mesmas concentram sua atenção nas duas guerras mundiais e na guerra fria, dando uma impressão de que houve uma guerra ininterrupta de $75 \operatorname{anos}^{54}$. Essa ideia não permite visualizar o ano de 1945 como um ponto de virada, uma virada para o melhor.

\footnotetext{
${ }^{50}$ HABERMAS, Jürgen. A constelação pós-nacional: ensaios políticos. Tradução de Márcio Seligmann- Silva. São Paulo: Littera Mundi, 2001, p. 59

${ }^{51}$ HABERMAS, Jürgen. A constelação pós-nacional: ensaios políticos. Tradução de Márcio Seligmann- Silva. São Paulo: Littera Mundi, 2001, p. 60.

${ }^{52}$ HABERMAS, Jürgen. A constelação pós-nacional: ensaios políticos. Tradução de Márcio Seligmann- Silva. São Paulo: Littera Mundi, 2001, p. 60.

${ }^{53}$ HABERMAS, Jürgen. A constelação pós-nacional: ensaios políticos. Tradução de Márcio Seligmann- Silva. São Paulo: Littera Mundi, 2001, p. 60.

${ }^{54}$ HABERMAS, Jürgen. A constelação pós-nacional: ensaios políticos. Tradução de Márcio Seligmann- Silva. São Paulo: Littera Mundi, 2001, p. 61.
} 


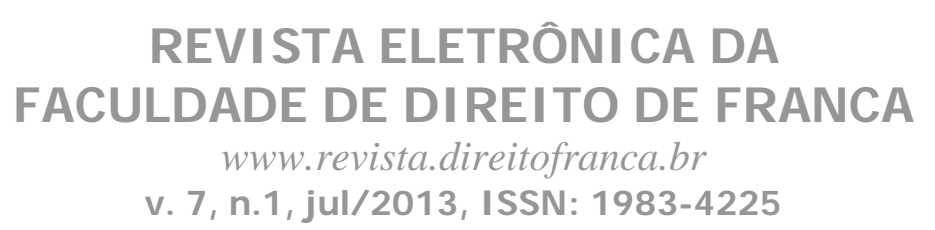

O fim da Segunda Guerra Mundial (1945) com a derrota das forças do eixo é um marco melhor para se analisar o século XX. A vitória dos aliados não apenas permitiu o desenvolvimento da democracia na República Federal da Alemanha, na Itália, no Japão e posteriormente em Portugal e na Espanha, como gerou uma série de desenvolvimentos políticos e até mesmo culturais ${ }^{55}$.

A mudança do clima cultural introduzida em 1945 também permitiu três desenvolvimentos políticos: a) a Guerra Fria; b) a descolonização e c) a construção do Estado social na Europa.

A guerra fria, uma competição armamentista grandiosa, só surge após 1945. E foi ela que deteve as nações ameaçadas sob o signo do terror, na medida em que um equilíbrio louco do terror (possibilidade de destruição recíproca) impediu o surgimento de uma guerra quente.

Também a partir de 1945 desenvolve-se com mais força o processo de descolonização, isto é, vários povos colonizados puseram de lado a dependência formal em relação aos colonizadores, alterando a geografia mundial. Esses povos tornaram-se países independentesembora frequentemente desunidos por guerras civis - membros da Assembleia Geral da ONU com os mesmosdireitos.

Por fim, a partir de 1945 desenvolve-se, nas democracias abastadas e pacíficas da Europa Ocidental e, em menor escala, nos EUA e em outros países, o Estado Social. Neste Estado há uma construçãoampla de direitos civis e pela primeira vez a realização efetiva de direitos sociais básicos, que aparecem como resposta do sistema capitalista ao sistema socialista que prometia grande quantidade de direitos sociais. Neste Estado Social a forma econômica altamente produtiva do capitalismo foi sujeitada de modo social a auto compreensão normativa de Estados constitucionais democráticos.

Após a Segunda Guerra Mundial, é certo que outra realidade se põe para o mundo. "O fracasso da Sociedade das Naçõesque, aliado ao recrudescimento do protecionismo comercial e à depressão econômica dos anos trinta, influenciariam as ações tomadas após 1945”,56. Os

\footnotetext{
${ }^{55}$ HABERMAS, Jürgen. A constelação pós-nacional: ensaios políticos. Tradução de Márcio Seligmann- Silva. São Paulo: Littera Mundi, 2001, p. 62.

${ }^{56}$ FALCÃO, Maurin Almeida. Livre-comércio: quecontextopolítico? Aspectoshistóricos das dificuldades dos paísesemdesenvolvimentoouemtransição, no acesso a mercados. Revista do Programa de MestradoemDireito do UniCEUB, Brasília,v. 2, n. 2, jul./dez. 2005, p. 6.
} 


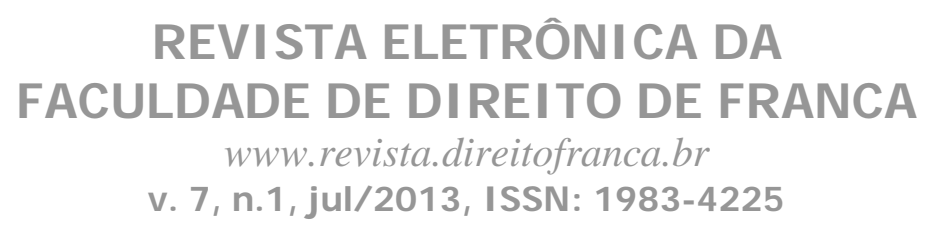

problemas do período entre guerras, marcado pelo protecionismo econômico e pelo nacionalismo, fizeram surgir uma união em torno de objetivos comuns, com o intuito de reduzir as tensões econômicas e políticas, preservando a paz e buscando melhorar o bem-estar da população ${ }^{57}$. Especialmente após 1960, começam a se difundir os acordos multilaterais de comércio, suplantando os acordos bilaterais, como mecanismos reguladores da vida econômica das nações ${ }^{58}$. Os Estados cedem parte de suas competências reguladoras para entidades de âmbito supranacional, para uma administração concentrada de certos setores da vida econômica, em especial do comércio ${ }^{59}$.

Por todos esses fatores, é que Habermas prefere analisar o século XX tendo o ano de 1945 como marco. Outrossim, Eric Hobsbawm também tem esse marco muito forte em sua obra, na medida em que ele considera o período que se seguiu a 1945 a era de ouro de século $\mathrm{XX}^{60}$. Martin van Creveld coloca esse marco como o fim do ideal do Estado ${ }^{61}$. Em todo caso, trata-se de marco essencial nessa evolução do Estado Nacional.

\section{O FIM DO SÉCULO XX E A CRISE DO ESTADO NACIONAL}

Ao final do breve século XX há uma grande mudança na configuração do mundo. "O breve século XX fora de guerras mundiais, quentes ou frias, feitas por grandes potências e seus aliados em cenários de destruição de massa cada vez mais apocalípticos, culminando no holocausto nuclear das superpotências, felizmente evitado. Esse perigo desaparecera visivelmente" ${ }^{2}$. Tal fato não significa que a era das guerras tenha acabado, mas apenas que não há mais o risco da guerra de efeitos apocalípticos entre as duas superpotências.

${ }^{57}$ NASSER, Rabih Ali. A liberalização do comérciointernacional nas normas do GATT- OMC. São Paulo: Ltr, 1999, p. 22.

${ }^{58}$ ALMEIDA, Paulo Roberto de. O Brasil e o multilateralismo econômico. PortoAlegre: Livraria do Advogado, 1999, p. 84.

59 ALMEIDA, Paulo Roberto de. O Brasil e o multilateralismo econômico. PortoAlegre: Livraria do Advogado, 1999, p. 85.

${ }^{60}$ HOBSBAWM, Eric. A era dos extremos: o breveséculo XX (1914 - 1991). Tradução de Marcos Santarrita. São Paulo: Companhia das Letras, 1995, p. 253.

${ }^{61}$ CREVELD, Martin van. Ascensão e declínio do Estado. Tradução de Jussara Simões. São Paulo: Martins Fontes, 2004, p. 269.

${ }^{62}$ HOBSBAWM, Eric. A era dos extremos: o breveséculo XX (1914 - 1991). Tradução de Marcos Santarrita. São Paulo: Companhia das Letras, 1995, p. 538 


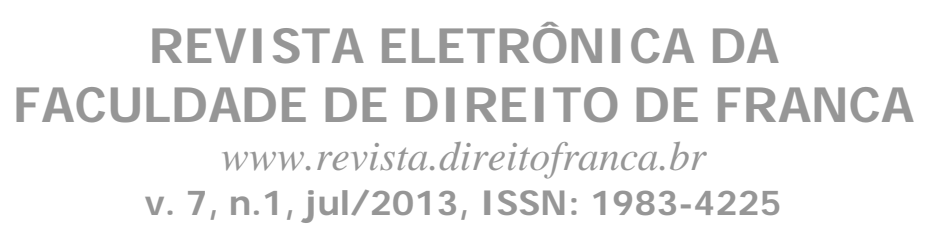

Nas economias mistas do ocidente, o Estado pôde influenciar nos âmbitos de produção e da distribuição com o intuito de alcançar crescimento, estabilidade dos preços e pleno emprego. Todavia, o final do século XX encontra-se sob o signo do risco estrutural de um capitalismo domesticado de modo social e do renascimento de um neoliberalismo indiferente ao social ${ }^{63}$. Surgem custos sociais, decorrente do aumento das disparidades salariais, que ameaçam exigir demais da capacidade de integração de uma sociedade liberal. Para os neoliberais, tal disparidade social é aceitável, na medida em que eles propõem um jogo de soma zero, no qual os grandes objetivos econômicos inevitáveis, podem ser obtidos à custa de objetivos sociais e políticos. Há quem fale inclusive em declínio do Estado ${ }^{64}$ ou até em um processo de tornar o Estado Nacional obsoleto $^{65}$.

Numa economia globalizada, os Estados só podem melhorar a capacidade competitiva internacional de suas posições, trilhando o caminho de uma autolimitação da capacidade de realização estatal. Tal situação justifica medidas de "desconstrução" que danificam a coesão social e que põem à prova a estabilidade democrática da sociedade ${ }^{66}$.Esses problemas econômicos das sociedades do bem-estar social podem ser explicados com base na mudança estrutural do sistema econômico mundial.

Desde seu surgimento, os estados nacionais sofreram mudanças nas suas funções e na sua própria concepção, mas nada que o afetasse tão profundamente. Apenas a partir do final do século XX, é que surgem mudanças econômicas radicais que afetam as atribuições do estado nacional, retirando-lhe o protagonismo, em especial na produção normativa, permitindo o ressurgimento da lex mercatoria ${ }^{67}$, gerando, em última análise, um processo de dispersão da produção normativa ${ }^{68}$.

\footnotetext{
${ }^{63}$ HABERMAS, Jürgen. A constelação pós-nacional: ensaios políticos. Tradução de Márcio Seligmann- Silva. São Paulo: Littera Mundi, 2001, p. 64.

${ }^{64}$ CREVELD, Martin van. Ascensão e declínio do Estado. Tradução de Jussara Simões. São Paulo: Martins Fontes, 2004, p. 481.

${ }^{65}$ FOWLER, Michael Ross; BUNCK, Julie Marie. Law, power and the sovereign state: the evolution and application of the concept of sovereignty. Penn State Press, 1995, p. 1.

${ }^{66}$ HABERMAS, Jürgen. A constelação pós-nacional: ensaios políticos. Tradução de Márcio Seligmann- Silva. São Paulo: Littera Mundi, 2001, p. 67.

${ }^{67}$ MICHAELS, Ralf. The true lex mercatoria: law beyond the state. Indiana Journal of Global Legal Studies Vol. 14 \#2, Summer 2007, p. 456.

${ }^{68}$ CASSESE, Sabino. A crise do Estado. Tradução de Ilse Pachoal Moreira e Fernanda Landucci Ortale. Campinas: Saberes, 2010, p. 72.
} 


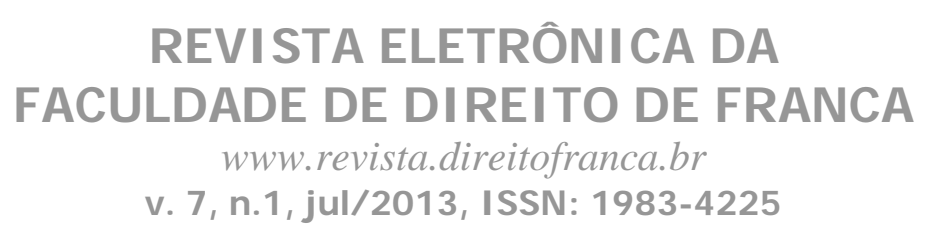

Em muitos casos, o Estado atua como mero espectador da atuação dos agentes privados ${ }^{69}$. Ademais, há uma drástica mudança em relação à ordem mundial passada, com o surgimento da internacionalização do Estado, a redução da capacidade estatal ${ }^{70}$ de garantir segurança dos cidadãos e integridade territorial, por si só e a própria evolução e ampliação do campo de aplicação do Direito Internacional ${ }^{71}$. Essas mudanças radicais são em boa parte fruto da globalização econômica, cuja concepção será mais bem explicada. Em todo caso, o que não se pode negar é a existência de uma crise na concepção e nas funções clássicas do Estado Nacional ${ }^{72}$. Esta crise vem tanto de cima, de entidades supranacionais, quanto de baixo pelos processos de desagregação interna do próprio Estado ${ }^{73}$.

Essa mudança de concepção do mundo traz o desenvolvimento para o campo central das preocupações e, nessa perspectiva, há uma mudança estrutural do sistema econômico mundial, que tem uma palavra chave: globalização.

\section{A GLOBALIZAÇÃO ECONÔMICA COMO CATALISADOR DAS MUDANÇAS DO ESTADO NACIONAL}

A globalização é uma expressão de sentido bastante variado, sendo entendida basicamente como "ações em fronteiras nas dimensões da economia, da informação, da ecologia, da técnica, dos conflitos transculturais e da sociedade civil”74, isto é, uma ligação geral entre indivíduos, organizações complexas e comunidades localizados em locais distintos. Fundamentalmente a globalização é a integração de pessoas e países, em razão da revolução dos transportes e das comunicações que derrubaram as barreiras artificiais que impediam o fluxo de bens, pessoas,

${ }^{69}$ FAZIO, Silvia. The harmonization of international commercial law. Alphen aan den Rijn: Kluwer Law International, 2007, p. 8.

${ }^{70}$ TANZI, Vito, The Demise of the Nation State? (August 1998). IMF Working Paper, Vol. , pp. 1-17, 1998. Available at SSRN: http://ssrn.com/abstract=882660. Acesso em 15/02/2011; CLARK, Ian. Globalization and international relations theory. New York: Oxford, 1999, p. 107.

${ }^{71}$ ROTH, André- Noël. O direito em crise: Fim do Estado moderno? In: FARIA, José Eduardo (org.). Direito $e$ globalização econômica. São Paulo: Malheiros, 1996, p. 18.

${ }_{72}$ FERRAJOLI, Luigi. A soberania no mundo moderno. Tradução de Carlo Coccioli e Marcio Lauria Filho. 2. Ed. São Paulo: Martins Fontes, 2007, p. 45.

${ }^{73}$ FERRAJOLI, Luigi. A soberania no mundo moderno. Tradução de Carlo Coccioli e Marcio Lauria Filho. 2. Ed. São Paulo: Martins Fontes, 2007, p. 48-49.

${ }^{74}$ BECK, Ulrich. O que é a globalização?Tradução de André Carone. São Paulo: Paz e Terra, 1999, p. 46. 


\section{REVI STA ELETRÔNI CA DA FACULDADE DE DI REITO DE FRANCA \\ www.revista.direitofranca.br \\ v. 7, n.1, jul/ 2013, I SSN: 1983-4225}

capitais, serviços e conhecimento através das fronteiras ${ }^{75}$. Trata-se em última análise da sobreposição do mundial sobre o nacional $^{76}$, não se limitando a matérias específicas ${ }^{77}$.

As ideias, os efeitos e as práticas que resultam desse fenômeno são extremamente variados, daí poder-se falar em globalizações, dada a multi dimensionalidade ${ }^{78}$ do fenômeno. Alguns autores destacam a questão sob a ótica das finanças e da propriedade do capital, dos mercados e das estratégias, da tecnologia, dos modos de vida e consumo (cultura), das capacidades regulatórias e da governança, da percepção e da consciência e também como unificação política do mundo e a globalização ${ }^{79}$. Há ainda quem afirme que ela abrange muitas coisas, desde o fluxo internacional de ideias e conhecimento, o compartilhamento de culturas, uma sociedade civil global e o movimento ambiental mundial ${ }^{80}$.

Outros nos propõe em quatro acepções do fenômeno, afirmando que, com um enfoque mais amplo, “a globalização é o processo pelo qual determinada condição ou entidade local estende a sua influência a todo o globo e, ao fazê-lo, desenvolve a capacidade de considerar como sendo local outra condição social ou entidade rival” ${ }^{81}$.Dentro dessa perspectiva, vale destacar que a globalização não deixa de ser um localismo bem sucedido, que extrapolou o âmbito inicial de suas fronteiras, isto é, a globalização é o reflexo da influência de determinado comportamento por todo o globo. Como exemplo dessa concepção, temos a expansão da língua inglesa como uma língua "universal” em detrimento de outras línguas que tinham o mesmo potencial, como a francesa.

Outra acepção da globalização seria o chamado globalismo localizado que representaria o impacto de práticas transnacionais nas condições locais, vale dizer, seria a forma como tais

\footnotetext{
${ }^{75}$ STIGLITZ, Joseph. Globalization and its discontents. New York: Penguin, 2002, p. 9.

${ }^{76}$ FARIA, José Eduardo. Direito e conjuntura. 2. Ed. São Paulo: Saraiva, 2010, p. 3.

77 ARNOLD, Rainer. Alcune riflessioni sulla nozione e sugli effetti dela globalizzazione. In: AMATO, Cristina; PONZANELLI, Giulio (a cura di). Global law v. local law: problemi dela globalizzazione giuridica. Torino: Giappichelli, 2006, p. 4.

${ }^{78}$ BONAGLIA, Federico; GOLDSTEIN, Andrea. Globalizzazione e sviluppo. 2. Ed. Bologna: Il mulino, 2008, p. 14; AUBY, Jean-Bernard. La globalization, le droitetl'État. 2. Ed. Paris: LGDJ, 2010, p. 18-20.

79 PETRELLA, Ricardo. Globalization and internationalization: the dynamics of the emerging world order. In: BOYER, Robert; DRACHE, Daniel (ed.). States against markets. London: Routledge, 1996, p. 66.

${ }^{80}$ STIGLITZ, Joseph. Globalização: como dar certo. Tradução Pedro Maia Soares. São Paulo: Companhia das Letras, 2007, p. 62.

81 SANTOS, Boaventura de Sousa. Por uma concepção multicultural de direitoshumanos. In: (org). Reconhecerparalibertar: os caminhos do cosmopolitismo multicultural. Rio de Janeiro: CivilizaçãoBrasileira, 2003, p. 433.
} 


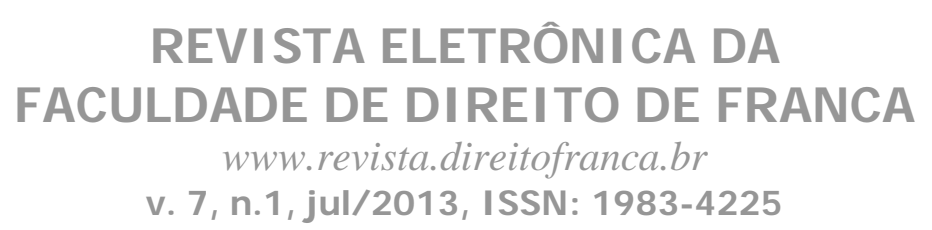

práticas se refletem no dia a dia de certa comunidade. A alteração da agricultura, de agricultura de subsistência para agricultura de exportação, seria um dos reflexos desse fenômeno. Uma terceira acepção, tomada por Boaventura de Sousa Santos, é o chamado cosmo politismo, entendido como "a solidariedade transnacional entre grupos explorados, oprimidos ou excluídos pela globalização hegemônica” ${ }^{22}$. O globalismo localizado e o localismo globalizado geram efeitos muitas vezes nefastos, que fazem surgir uma reação em nível global, possível graças à revolução da tecnologia, da informação e da comunicação. Essa reação, que se manifesta por um conjunto vasto e heterogêneo de medidas, movimentos e organizações, é que representa o cosmopolitismo nessa visão. Diretamente ligada a esta última concepção, o mesmo autor nos apresenta a quarta acepção, entendida como a "emergência de temas que, pela sua natureza, são tão globais quanto o próprio planeta” ${ }^{\star 3}$. Surge, nesse ponto, o chamado patrimônio comum da humanidade que representaria esse conjunto de preocupações globais, que ensejam movimentos também globais para a defesa desse patrimônio comum.

Sem a pretensão de querer esgotar as acepções, é certo que as apresentadas têm o condão de ilustrar a multiplicidade de efeitos que a globalização está gerando e consequentemente os desafios que surgem dessas globalizações. Para os fins do presente trabalho, porém, serão analisados especificamente os desafios impostos especificamente pela globalização econômica.

A globalização econômica, embora seja a mais estudada, é apenas uma dimensão da emergente reconfiguração do mundo ${ }^{84}$. Ela representa a "intensificação dos fenômenos de troca, de comunicação e de trânsito para além das fronteiras nacionais” ${ }^{85}$ ou, em outras palavras, a "interligação de mercados nacionais através do aumento da circulação entre eles de bens, serviços e capitais" ${ }^{\prime \prime}$.

82 SANTOS, Boaventura de Sousa. Por uma concepção multicultural de direitoshumanos. In: (org). Reconhecerparalibertar: os caminhos do cosmopolitismo multicultural. Rio de Janeiro: CivilizaçãoBrasileira, 2003, p. 437.

83 SANTOS, Boaventura de Sousa. Por uma concepção multicultural de direitoshumanos. In: (org). Reconhecerparalibertar: os caminhos do cosmopolitismo multicultural. Rio de Janeiro: Civilização Brasileira, 2003, p. 437.

${ }^{84}$ PETRELLA, Ricardo. Globalization and internationalization: the dynamics of the emerging world order. In: BOYER, Robert; DRACHE, Daniel (ed.). Statesagainstmarkets. London: Routledge, 1996, p. 62.

${ }^{85}$ HABERMAS, Jürgen. A constelação pós-nacional: ensaios políticos. Tradução de Márcio Seligmann- Silva. São Paulo: Littera Mundi, 2001, p. 84.

${ }^{86}$ NUSDEO, Ana Maria de Oliveira. Defesa da concorrência e globalizaçãoeconômica: o controle da concentração de empresas. São Paulo: Malheiros, 2002, p. 137-138. 


\section{REVI STA ELETRÔNI CA DA \\ FACULDADE DE DI REITO DE FRANCA \\ www.revista.direitofranca.br \\ v. 7, n.1, jul/ 2013, I SSN: 1983-4225}

De forma mais detalhada, afirma-se que:

Por globalização se entende basicamente essa integração sistêmica da economia em nível supranacional, deflagrada pela crescente diferenciação estrutural e funcional dos sistemas produtivos pela subsequente ampliação das redes empresariais, comerciais e financeiras em escala mundial, atuando de modo cada vez mais independente dos controles políticos e jurídicos ao nível nacional, esse fenômeno, como afirma Habermas acaba comprometendo mortalmente a ideia republicana de comunidade ${ }^{87}$.

Em outras palavras, ela representaria:

A integração das economias nacionais em uma economia internacional através do comércio, do investimento estrangeiro direto (por parte de corporações e multinacionais), fluxos de capital de curto prazo, fluxo internacional de trabalhadores e pessoas em geral e fluxos de tecnologia. ${ }^{88}$

Portanto, a ideia geral da globalização econômica é a formação de um mercado global e a perda de importância das fronteiras para o exercício das atividades econômicas, vale dizer, as atividades econômicas alcançam um grau de integração temporal e geográfico. Uma das principais características desse fenômeno é a globalização dos mercados financeiros, permitindo que os fluxos de capital sejam mais amplos, abrangendo cada vez mais países. O movimento global de capitais é o fator mais importante para essa modalidade de globalização ${ }^{89}$.

Esse fenômeno representa o triunfo do mercado, que pode ser atribuído a três fatores fundamentais ${ }^{90}$. Em primeiro lugar, o mercado triunfou em razão de sua eficiência, vale dizer, o sistema capitalista, apesar de todos os seus problemas, se mostrou como o mais eficiente para geração e distribuição de riquezas. Em segundo lugar, houve a queda do sistema econômico socialista, reforçando a primazia do sistema capitalista. Por fim, a expansão tecnológica e das comunicações foi determinante no surgimento desse fenômeno.

Além disso, há uma internacionalização das estratégias corporativas, havendo cada vez mais estratégias de competição em escala global ${ }^{91}$. Outrossim, há uma difusão de tecnologias que

\footnotetext{
${ }^{87}$ FARIA, José Eduardo. O direito na economia globalizada. São Paulo: Malheiros, 2000, p. 52.

${ }^{88}$ BHAGWATI, Jagdish. Emdefesa da globalização. Tradução de Regina Lyra. Rio de Janeiro: Elsevier, 2004, p. 34.

89 PETRELLA, Ricardo. Globalization and internationalization: the dynamics of the emerging world order. In: BOYER, Robert; DRACHE, Daniel (ed.). States against markets. London: Routledge, 1996, p. 68.

${ }^{90}$ IUDICA, Giovanni. Law \& globalization. Revista de direito bancário e do mercado de capitais. São Paulo, anto13, n.47, jan-mar 2010, p. 176-177.

${ }^{91}$ NUSDEO, Ana Maria de Oliveira. Defesa da concorrência e globalizaçãoeconômica: o controle da concentração de empresas. São Paulo: Malheiros, 2002, p. 138.
} 


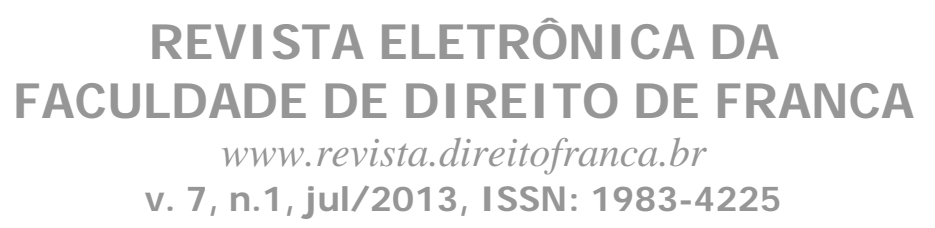

passam a ser acessíveis em todo o mundo de forma cada vez mais rápida. Há ainda uma homogeneização das práticas de consumo que passam a ter cada vez mais um caráter comum, embora fatores culturais e religiosos ainda tenham um peso fundamental nessas escolhas. Nesse cenário, os agentes econômicos ganham importância e passar a ser considerados protagonistas ${ }^{92}$.Em suma, por força da globalização vê-se claramente a formação de um mercado unificado, no qual os mesmos produtos são vendidos e as mesmas imagens e informações são transmitidas, isto é, há uma mudança radical na economia e o surgimento de novos protagonistas, em especial pela crise do Estado nacional e do Direito ${ }^{93}$.

\section{IMPACTOS DA GLOBALIZAÇÃO ECONÔMICA SOBRE O ESTADO NACIONAL}

A globalização econômica trouxe consigo uma reestruturação da economia caracterizada especialmente pela mudança nos padrões de produção, pela união de mercados financeiros, pelo aumento da importância das multinacionais, pelo aumento da importância do intercâmbio, pelo crescimento da integração regional, pelo ajuste estrutural e privatização, pela hegemonia de conceitos neoliberais de relações econômicas, pelo renovado interesse no império do direito pelo surgimento de novos protagonistas ${ }^{94}$. "A crise da unidade dos Estados e a crise de sua soberania econômica convergem em um resultado único, a constituição de ordens supranacionais organizadas em redes em vez de hierarquias" ${ }^{\circ 5}$.

A existência desta nova realidade econômica não é facilmente adaptável à configuração tradicional do estado nacional moderno, podendo-se falar até em crise do Estado ${ }^{96}$.Se antes a

\footnotetext{
${ }^{92}$ IUDICA, Giovanni. Law \& globalization. Revista de direito bancário e do mercado de capitais. São Paulo, anto13, n.47, jan-mar 2010, p. 178.

93 IUDICA, Giovanni. Law \& globalization. Revista de direito bancário e do mercado de capitais. São Paulo, anto13, n.47, jan-mar 2010, p. 180.

${ }^{94}$ DEZALAY, Ives; TRUBEK, David M. A reestruturação global e o direito: a internacionalização dos campos jurídicos e a criação de espaços transacionais. In: FARIA, José Eduardo (org.). Direito e globalização econômica. São Paulo: Malheiros, 1996, p. 29-30.

${ }^{95}$ CASSESE, Sabino. A crise do Estado. Tradução de Ilse Pachoal Moreira e Fernanda Landucci Ortale. Campinas: Saberes, 2010, p. 31.

${ }_{96}$ ZIMMERMANN, Augusto. Teoria geral do federalismo democrático. Rio de Janeiro: Lumen Juris, 1999, p. 25.
} 


\section{REVI STA ELETRÔNI CA DA FACULDADE DE DI REITO DE FRANCA \\ www.revista.direitofranca.br \\ v. 7, n.1, jul/ 2013, I SSN: 1983-4225}

economia levava em conta o Estado, agora o Estado deve levar em conta a economia ${ }^{97}$. O Estado “já é demasiado grande para as coisas pequenas e demasiado pequeno para as coisas grandes”98.

Diversas funções eram atribuídas para esse Estado Nacional moderno, Habermas prefere identificar quatro funções primordiais, isto é, para ele, o Estado Nacional moderno surgiu como: a) Estado administrador/fiscal; b) Estado Territorial; c) Estado Nacional e d) Estado democrático de direito e social ${ }^{99}$.

O Estado administrador/fiscal era concebido como o resultado da separaçãoentre o Estado e a sociedade, isto é, “a sociedade, para atuar politicamente sobre si mesma, deve destacar um subsistema que seja especializado em decisões que agreguem a coletividade”100. Ficam reservadas ao Estado o monopólio do usolegítimo da violência e as competências reguladoras públicas mais importantes. Na sociedade moderna, onde foi afastada a autodefesa, salvo hipóteses excepcionais, sendo monopólio do Estado ação física legítima, compete ao mesmo solucionar a grande maioria dos conflitos de interesses, a fim de assegurar a paz social. O Estado dita regras que disciplinam as relações sociais - o direito objetivo- e soluciona os conflitos de interesses aplicando as regras do direito objetivo, por meio do processo.

O Direito não é apenas um meio de organização da administração, ele protege os cidadãos do Estado, na medida em que conduz as interações entre eles. O direito organiza o Estado administrativo, mas também impõe limites à atuação do Estado administrativo, protegendo os indivíduos da interferência ilegítima do Estado. Para essa atuação administrativa do Estado é essencial a captação de recursos, pois sem recursos não há atividade que possa ser desenvolvida. Neste particular, surge o Estado Fiscal que é a face do Estado responsável pela captação de recursos na esfera privada, especialmente por meio dos chamados tributos.

Levando-se emconta a forma de imposição do direitopositivo, isto é, o âmbito de atuação coercitiva do direito imposto pelo Estado, a demarcação social da comunidade política deve ser combinada com a delimitação territorial. O Estado deve terumterritório, no qual se circunscreve o

\footnotetext{
${ }^{97}$ CASSESE, Sabino. A crise do Estado. Tradução de Ilse Pachoal Moreira e Fernanda Landucci Ortale. Campinas: Saberes, 2010, p. 46.

${ }_{98}^{98}$ FERRAJOLI, Luigi. A soberania no mundo moderno. Tradução de Carlo Coccioli e Marcio Lauria Filho. 2. Ed. São Paulo: Martins Fontes, 2007, p. 50.

${ }^{99}$ HABERMAS, Jürgen. A constelação pós-nacional: ensaios políticos. Tradução de Márcio Seligmann- Silva. São Paulo: Littera Mundi, 2001, p. 80.

${ }^{100}$ HABERMAS, Jürgen. A constelação pós-nacional: ensaios políticos. Tradução de Márcio Seligmann- Silva. São Paulo: Littera Mundi, 2001, p. 80
} 


\section{REVI STA ELETRÔNI CA DA \\ FACULDADE DE DI REITO DE FRANCA \\ www.revista.direitofranca.br \\ v. 7, n.1, jul/ 2013, I SSN: 1983-4225}

âmbito de validade de uma ordem jurídica que ele mesmo impõe. Dentro das fronteiras do Estado territorial, aparece o povo do Estado como sujeito potencial de uma auto legislação de cidadãos reunidos e a sociedadecomo o objetopotencial dessa atividade. De outrolado, aparece a soberania do Estado territorial como direito ao reconhecimento recíproco da integridade das fronteirasestatais ${ }^{101}$.

Sob a ótica política, os Estados que se desenvolveram a partir da revolução francesa e da revolução americana, se impuseram mundialmente como um modelo de Estado Democrático. A democracia deve ser entendida como uma associação de cidadãos, livres e iguais que governam a si mesmos. Nem todos os Estados Nacionais eram ou são democráticos, mas onde surgiu a democracia de formaocidental, ela assumiu a forma do Estado Nação ${ }^{102}$. O Estado territorial, a nação e uma economia constituída dentro das fronteiras nacionais formaram então uma constelação histórica na qual o processo democrático pode assumir uma figura institucional mais ou menos convincente ${ }^{103}$.

Na Europa do pós-guerra os quatro aspectos do Estado se desenvolveram de modo satisfatório, podendo-se afirmar que boa parte dos Estados da Europa ocidental se encaixava no conceito de Estado nacional. Todavia, a partir dos anos 70, o Estado nacional passou a sofrer pressões pelo fenômeno da globalização, que gerou uma corrosão da identidade estatal e pública $^{104}$ e afetou diretamente as condições de funcionamento e de legitimação de uma democracia de massa de Estado social ${ }^{105}$.

De início, convém destacar que a globalização afeta a segurança jurídica e a efetividade do Estado. Graças à quebra do equilíbrio ecológico e à capacidade de destruição embutida na aplicação de novas tecnologias, novos riscos surgiram (camada de ozônio, chuva ácida, acidentes nucleares ...) . Tais riscos não se atêm as fronteiras de um Estado e, por isso, também não se deixam mais controlar nos âmbitos nacionais. Além disso, o crime organizado torna as fronteiras

\footnotetext{
${ }^{101}$ HABERMAS, Jürgen. A constelação pós-nacional: ensaios políticos. Tradução de Márcio Seligmann- Silva. São Paulo: Littera Mundi, 2001, p. 82.

102 HABERMAS, Jürgen. A constelação pós-nacional: ensaios políticos. Tradução de Márcio Seligmann- Silva. São Paulo: Littera Mundi, 2001, p. 80.

${ }^{103}$ HABERMAS, Jürgen. A constelação pós-nacional: ensaios políticos. Tradução de Márcio Seligmann- Silva. São Paulo: Littera Mundi, 2001, p. 78.

${ }^{104}$ CASSESE, Sabino. A crise do Estado. Tradução de Ilse Pachoal Moreira e Fernanda Landucci Ortale. Campinas: Saberes, 2010, p. 59.

${ }^{105}$ HABERMAS, Jürgen. A constelação pós-nacional: ensaios políticos. Tradução de Márcio Seligmann- Silva. São Paulo: Littera Mundi, 2001, p. 84.
} 


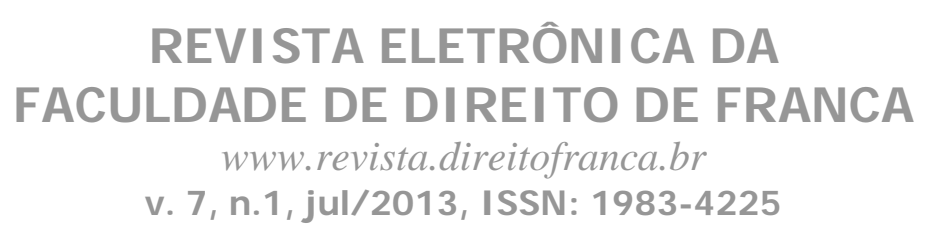

dos Estados cada vez mais porosas, dificultando também a efetividade de atuação do Estado administrativo. A tarefa de proteção é sem dúvida uma das principais tarefas desse Estado administrativo $^{106}$. A capacidadeque o Estado vem perdendo nesses aspectos pode ser compensada em nível internacional por organizações globais. De todo modo, é inegável a perda da capacidade estatal de garantir, por si só, a segurança dos seus cidadãos e asua integridade territorial $^{107}$.

Outrossim, a mobilidade de capital dificulta a atuação do Estado Fiscal na apreensão de recursos. Os paraísos fiscais são cada vez mais acessíveis aos empresários. Além disso, o acirramento da concorrência conduz à redução de ganhosfiscais, sobpena de se gerar uma grandeemigração de capitais. "Numa situação extrema, os Estados chegam ao ponto de não mais conseguirem estabelecer os tributos a serem aplicados sobre a riqueza - esta é que transnacionalizando-se, passa a escolher onde pagá-los” ${ }^{108}$.

Por essas razões, a expressão Estado enxuto vem se impondo pelas possibilidades de atuação do Estado no mundo globalizado ${ }^{109}$.As funções do Estado social não poderão mais ser preenchidas por ele, no mesmo nível que já o foram ${ }^{110}$. A intervenção estatal deve ser cada vez menor dentro de uma economia globalizada, na medida em que o próprio poder de coação dos Estados é cada vez menor ${ }^{111}$, mas ainda tem sua importância.

Nessa perspectiva, vários princípios surgem para redefinir as funções estatais, a saber: a subsidiariedade, a supletividade, a proximidade e a parceria ${ }^{112}$. A subsidiariedade limitando a atuação estatal apenas aos casos de falha dos mecanismos próprios da sociedade. A supletividade significa o incentivo estatal a atuação a iniciativas privadas. A proximidade pretende uma análise

\footnotetext{
${ }^{106}$ FLEINER-GESTER, Tomas. Teoria geral do Estado. Tradução de Marlene Holzhausen. São Paulo: Martins Fontes, 2006, p. 587.

${ }^{107}$ ROTH, André- Noël. O direito em crise: Fim do Estado moderno? In: FARIA, José Eduardo (org.). Direito $e$ globalização econômica. São Paulo: Malheiros, 1996, p. 18; ZIMMERMANN, Augusto. Teoria geral do federalismo democrático. Rio de Janeiro: Lumen Juris, 1999, p. 27.

${ }^{108}$ FARIA, José Eduardo. O direito na economia globalizada. São Paulo: Malheiros, 2000, p. 23.

${ }^{109}$ HABERMAS, Jürgen. A constelação pós-nacional: ensaios políticos. Tradução de Márcio Seligmann- Silva. São Paulo: Littera Mundi, 2001, p. 88.

${ }^{110}$ FERRAJOLI, Luigi. A soberania no mundo moderno. Tradução de Carlo Coccioli e Marcio Lauria Filho. 2. Ed. São Paulo: Martins Fontes, 2007, p. 51; CLARK, Ian. Globalization and international relations theory. New York: Oxford, 1999, p. 45.

${ }^{111}$ ROTH, André- Noël. O direito em crise: Fim do Estado moderno? In: FARIA, José Eduardo (org.). Direito $e$ globalização econômica. São Paulo: Malheiros, 1996, p. 18.

112 CHEVALLIER, Jacques. O Estado pós-moderno. Tradução de Marçal Justen Filho. Belo Horizonte: Fórum, 2009, p. 59-61.
} 


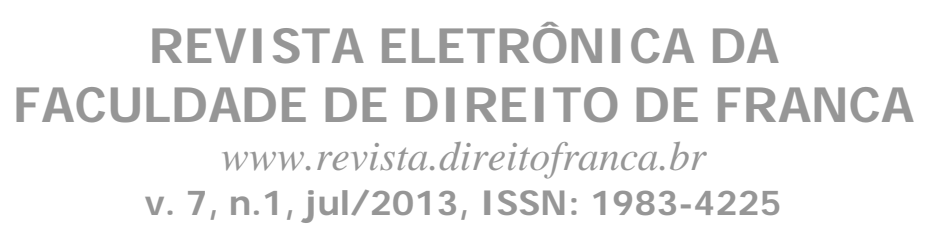

dos problemas em instâncias mais próximas dos cidadãos. E, por fim, a parceria envolve a associação de atores públicos e privados, como as parcerias público-privadas.

Além disso, a existência de um mercado mundial e a expansão da atuação das empresas demonstram que a ideia da autarquia como um estado possível ou mesmo desejável deve ser descartada no mundo real. Nenhum Estado é capaz de suprir todas as suas necessidades. Tal realidade implica a existência de laços entre as economias de vários países. Sobretudo, com a globalização, esses laços entre as economias nacionais vêm ficando cada vez mais estreitos, com a expansão da atuação das empresas multinacionais, de modo que pode se falar hoje já em interdependência, para descrever as relações econômicas internacionais ${ }^{113}$. A interdependência, que pauta todas as relações econômicas contemporâneas, traz à tona a complementaridade existentes entre as várias economias nacionais ${ }^{114}$. Uma economia depende da outra e vice-versa. Não há economia que sobreviva sem tais ligações. As economias nacionais são cada vez mais afetadas pelos "equilíbrios externos e pelos vínculos de interdependência que se estabelecem em escala planetária”"115. Dentro dessa ideia, há uma espécie de desterritorialização ${ }^{116}$ das atividades econômicas, desorientando os Estados que sempre tiveram uma atuação territorial ${ }^{117}$.

Por fim, a globalização afeta também a legitimação democrática do Estado Nacional. O processo democrático deve tentar afastar os perigos de uma perda da solidariedade tentando corresponder a critérios reconhecidos de justiçasocial. Para permanecer uma fonte de solidariedade, o status de cidadão deve manter um valor de uso e também se fazer pagar na moeda dos direitos sociais, ecológicos e culturais ${ }^{118}$.

A globalização influencia a política social na medida em que representa uma redução da entrada de tributos. Além disso, os governos nacionais vêm perdendo a capacidade de influência

\footnotetext{
${ }^{113}$ ALMEIDA, Paulo Roberto de. O Brasil e o multilateralismo econômico. PortoAlegre: Livraria do Advogado, 1999, p. 34.

${ }^{114}$ ALMEIDA, Paulo Roberto de. O Brasil e o multilateralismo econômico. PortoAlegre: Livraria do Advogado, 1999, p. 39.

115 ALMEIDA, Paulo Roberto de. O Brasil e o multilateralismo econômico. PortoAlegre: Livraria do Advogado, 1999, p. 35.

${ }^{116}$ TANZI, Vito, The Demise of the Nation State? (August 1998). IMF Working Paper, Vol. , pp. 1-17, 1998. Available at SSRN: http://ssrn.com/abstract=882660. Acesso em 15/02/2011; ROCHA, Luiz Alberto G. S. Estado, democracia e globalização. Rio de Janeiro: Forense, 2008, p. 163.

${ }^{117}$ CASSESE, Sabino. A crise do Estado. Tradução de Ilse Pachoal Moreira e Fernanda Landucci Ortale. Campinas: Saberes, 2010, p. 41.

${ }^{118}$ HABERMAS, Jürgen. A constelação pós-nacional: ensaiospolíticos. Tradução de Márcio Seligmann- Silva. São Paulo: Littera Mundi, 2001, p. 98.
} 


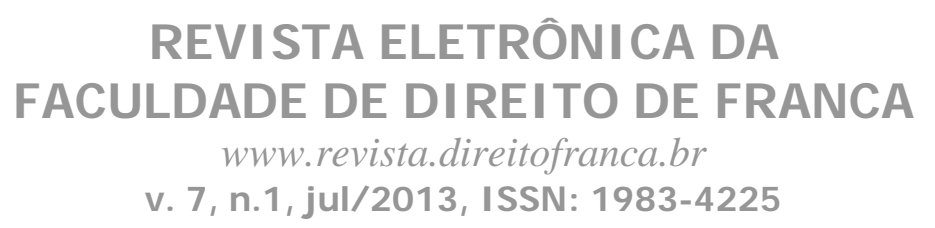

política no circuito econômico mais amplo. Nos mercados globais alterou-se o equilíbrio das forças, reduzindo a capacidade de ação política dos atores estatais e aumento o poder de influência das corporações multinacionais. O dinheiro substitui o poder ${ }^{119}$ e apenas o poder se deixa democratizar, o dinheiro não.

\section{A GLOBALIZAÇÃO ECONÔMICA E A SOBERANIA: NECESSIDADE DE RECONSTRUÇÃO DO CONCEITO}

Além de impactar o modo de produção do Direito e as funções clássicas do Estado, a globalização econômica também impacta um dos principais elementos da concepção do Estado Nacional: a soberania, na medida em que é deste elemento que o Estado deduz o direito de se organizar e de estabelecer o direito aplicável a sua população ${ }^{120}$. Tal elemento sempre foi muito discutido e posto em xeque por diversos autores há algum tempo, tendo inclusive Leon Duguit falado em eclipse da soberania ${ }^{121}$ já no início do século XX. Sabino Cassese, por sua vez, também afirma que háuma crise do estado a partir do início do século $\mathrm{XX}^{122}$. Apesar disso, as maiores discussões sobre esse elemento foram aumentando e ganhando importância com a globalização econômica, falando-se atualmente em fim da soberania ${ }^{123}$, recuo da soberania ${ }^{124}$ ou ao menos na reconfiguração desse conceito. Os fluxos globais não são novos, mas agora se tornaram efetivamente mais problemáticos para a ideia da soberania ${ }^{125}$.

\subsection{A CONCEPÇÃO CLÁSSICA DA SOBERANIA}

${ }^{119}$ HABERMAS, Jürgen. A constelação pós-nacional: ensaiospolíticos. Tradução de Márcio Seligmann- Silva. São Paulo: Littera Mundi, 2001, p. 100.

${ }^{120}$ FLEINER-GESTER, Tomas. Teoria geral do Estado. Tradução de Marlene Holzhausen. São Paulo: Martins Fontes, 2006, p. 218.

${ }^{121}$ DUGUIT, León. Law in the modern state. Translated by Frida and Harold Laski. New York: Huebsch, 1919, p. 131.

${ }^{122}$ CASSESE, Sabino. A crise do Estado. Tradução de Ilse Pachoal Moreira e Fernanda Landucci Ortale. Campinas: Saberes, 2010, p. 13.

${ }^{123}$ BARTELSON, Jens. A genealogy of sovereignty. Cambridge: Cambridge University Press, 1995, p. 246.

${ }^{124}$ CASSESE, Sabino. A crise do Estado. Tradução de Ilse Pachoal Moreira e Fernanda Landucci Ortale. Campinas: Saberes, 2010, p. 55.

${ }^{125}$ KRASNER, Stephen. D. Sovereignty: organized hypocrisy. Princeton: Princeton University Press, 1999, p. 223. 


\section{REVI STA ELETRÔNI CA DA \\ FACULDADE DE DI REITO DE FRANCA \\ www.revista.direitofranca.br \\ v. 7, n.1, jul/ 2013, I SSN: 1983-4225}

Para entender as discussões que ora se apresentam sobre a soberania, é fundamental analisar inicialmente a sua concepção clássica. Embora o estudo desse elemento possa remontar ao direito romano ${ }^{126}$, passando pela renascença e pela era clássica ${ }^{127}$, para os fins do presente trabalho, será utilizada como ponto de partida a teoria desenvolvida por Jean Bodin, como primeiro sistematizador, já que sua obra (Os seis livros da república) é considerada como um marco na teoria da soberania ${ }^{128}$, sem olvidar a importância das obras de Machiavel, Hobbes e outros.

Jean Bodin define a soberania como "o poder absoluto e perpétuo de uma república" 129 . Ele explica que o poder é perpétuo porque "pode acontecer que se dê poder absoluto a um ou a vários por certo tempo que, uma vez expirado, faz com que estes não sejam nada mais do que súditos"130. E completa afirmando que o poder é absoluto, de modo que "aqueles que são soberanos não estejam de forma alguma sujeitos aos comandos de outrem”"131. Trata-se de um poder que não se submete a nenhum outro, a não ser às leis divinas e naturais ${ }^{132}$, não havendo necessidade de obedecer às leis de seus predecessores.

Prossegue Bodin, identificando as marcas características da soberania, sendo a primeira "o poder de dar a lei a todos em geral e a cada um em particular" ${ }^{133}$. Outra marca identificada por ele é o poder de declarar guerra ou tratar a paz, ressaltando a importância dessa marca para a ruína ou o sucesso do Estado ${ }^{134}$. Dentro da mesma linha de entendimento, a terceira marca da

\footnotetext{
${ }^{126}$ DUGUIT, León. Law in the modern state. Translated by Frida and Harold Laski. New York: Huebsch, 1919, p. 2.

${ }^{127}$ BARTELSON, Jens. A genealogy of sovereignty. Cambridge: Cambridge University Press, 1995, p. 85-86.

${ }^{128}$ FLEINER-GESTER, Tomas. Teoria geral do Estado. Tradução de Marlene Holzhausen. São Paulo: Martins Fontes, 2006, p. 222-226; MENEZES, Aderson. Teoria Geral do Estado. 2. Ed. Rio de Janeiro: Forense, 1967, p. 146.

${ }^{129}$ BODIN, Jean. Os seis livros da República: livro primeiro. Tradução de José Ignácio Coelho Mendes Neto. São Paulo: Ícone, 2011, p. 195.

${ }^{130}$ BODIN, Jean. Os seis livros da República: livro primeiro. Tradução de José Ignácio Coelho Mendes Neto. São Paulo: Ícone, 2011, p. 197.

${ }^{131}$ BODIN, Jean. Os seis livros da República: livro primeiro. Tradução de José Ignácio Coelho Mendes Neto. São Paulo: Ícone, 2011, p. 206.

${ }^{132}$ BODIN, Jean. Os seis livros da República: livro primeiro. Tradução de José Ignácio Coelho Mendes Neto. São Paulo: Ícone, 2011, p. 207.

${ }^{133}$ BODIN, Jean. Os seis livros da República: livro primeiro. Tradução de José Ignácio Coelho Mendes Neto. São Paulo: Ícone, 2011, p. 298.

${ }^{134}$ BODIN, Jean. Os seis livros da República: livro primeiro. Tradução de José Ignácio Coelho Mendes Neto. São Paulo: Ícone, 2011, p. 301.
} 


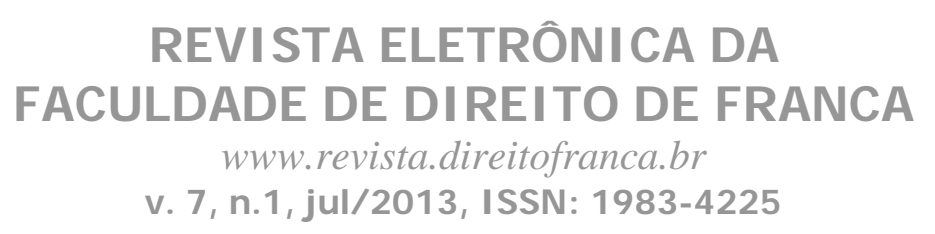

soberania seria o poder de "instituir os principais oficiais"135, sem prejuízo da possibilidade de delegação dessa função, desde que a confirmação e provisão tocassem ao soberano. A quarta marca da soberania seria a última alçada, isto é, que seria o último recurso ao soberano contra decisões jurisdicionais ${ }^{136}$. A quinta marca seria o poder de conceder graças e indultos aos condenados $^{137}$. Ele ainda aponta a medida, os pesos e a moeda como direitos da soberania ${ }^{138}$, bem como o poder de instituir tributos.

Embora tal concepção seja extremamente radical em alguns pontos, é certo que ela serviu de ponto de partida para a consolidação da ideia de soberania, com a apresentação de vários conceitos no mesmo sentido, ao menos no que tange ao cerne do conceito.

Herman Hellerafirma como uma das teses centrais que "soberania é a propriedade de uma unidade de ação e de decisão universal sobre um território, por meio da qual para garantir o direito se afirma de modo absoluto eventualmente contra o próprio direito" ${ }^{139}$. Tal opinião, porém, é muito radical, na medida em que o absolutismo da soberania sempre foi discutível pela própria existência do direito internacional. Apesar disso, a exposição desse conceito serve para mostrar a influência da obra de Bodin no desenvolvimento da teoria da soberania.

Miguel Reale, por sua vez, afirma que politicamente a soberania "é o poder que tem uma Nação e organizar-se livremente e de fazer valer dentro de seu território a universalidade de suas decisões para a realização do bem comum” ${ }^{140}$. Para o mesmo autor, juridicamente a soberania representaria "a qualidade que o Estado possui na esfera de sua competência jurídica de ser supremo independente e definitivo, dispondo, portanto, de decisões ditadas em último grau pela sua própria vontade e que pode impor inclusive pela força coativa” ${ }^{\text {"141 }}$. De modo similar, Aderson Menezes afirma que a soberania como competência é um conceito jurídico que representa o

\footnotetext{
${ }^{135}$ BODIN, Jean. Os seis livros da República: livro primeiro. Tradução de José Ignácio Coelho Mendes Neto. São Paulo: Ícone, 2011, p. 308.

${ }^{136}$ BODIN, Jean. Os seis livros da República: livro primeiro. Tradução de José Ignácio Coelho Mendes Neto. São Paulo: Ícone, 2011, p. 311.

${ }^{137}$ BODIN, Jean. Os seis livros da República: livro primeiro. Tradução de José Ignácio Coelho Mendes Neto. São Paulo: Ícone, 2011, p. 314.

${ }^{138}$ BODIN, Jean. Os seis livros da República: livro primeiro. Tradução de José Ignácio Coelho Mendes Neto. São Paulo: Ícone, 2011, p. 318.

${ }^{139}$ HELLER, Herman. La sovranitáedaltriscritti sulladottrinadeldiritto e dellostato. Milano: Giuffrè, 1987, p. 244, tradução livre de "sovranità è laproprietàdiun'unitàdiazione e didecisioneuniversale sul territorio, in forzadellaquale per garantireildiritto essa si afferma in modo assoluto eventualmente ache controildiritto".

${ }^{140}$ REALE, Miguel. Teoria do Direito e do Estado. 5. Ed. São Paulo: Saraiva, 2000, p. 140.

${ }^{141}$ MENEZES, Aderson. Teoria Geral do Estado. 2. Ed. Rio de Janeiro: Forense, 1967, p. 144.
} 


\section{REVI STA ELETRÔNI CA DA \\ FACULDADE DE DI REITO DE FRANCA \\ www.revista.direitofranca.br \\ v. 7, n.1, jul/ 2013, ISSN: 1983-4225}

direito de tomar decisões obrigatórias para os outros (editar leis), já “a soberania como plenitude de poder é um conceito político e significa simples o poder de comandar outros” ${ }^{142}$. Trata-se de um princípio organizador da realidade política dos Estados ${ }^{143}$.Em suma, “a soberania é um poder de decisão em última instância, e esta capacidade de impor a vontade própria em última instância"144, vale dizer, a "soberania é uma autoridade superior que não pode ser limitada por nenhum outro poder" ${ }^{145}$, ela representa a demarcação de uma autoridade política dentro de limites territoriais ${ }^{146}$.

Trata-se da ideia fundamental de um poder de comando de última instância ${ }^{147}$ que não se submete a nenhum outro poder, falando-se em soberania externa para reconhecer a igualdade com os demais e em soberania interna para evitar interferências externas. As regras da soberania dão aos estados autoridade plena sobre atividade dentro das suas fronteiras e proíbe a intervenção nos negócios internos de outros Estados ${ }^{148}$. Em síntese, são corolários da soberania: a ausência de subordinação orgânica a outros sujeitos de direito internacional, a presunção de regularidade dos atos estatais, a autonomia constitucional e o direito de participar das relações internacionais ${ }^{149}$.

\subsection{ATRIBUTOS CLÁSSICOS DA SOBERANIA}

Dentro dessa concepção clássica, devem ser explicitados os atributos clássicos desse poder que é a soberania. Alguns autores sustentam que a soberania nessa visão clássica se caracterizaria pela unidade e indivisibilidade ${ }^{150}$. André Lupi ${ }^{151}$ afirma que, na obra de Bodin, a soberania seria perpétua, absoluta, indivisível, intransmissível, indelegável, inalienável e imprescritível. Outros afirmam, que os atributos da soberania são a unidade, a indivisibilidade, a

\footnotetext{
${ }^{142}$ FLEINER-GESTER, Tomas. Teoria geral do Estado. Tradução de Marlene Holzhausen. São Paulo: Martins Fontes, 2006, p. 232. No mesmo sentido: REALE, Miguel. Teoria do Direito e do Estado. 5. Ed. São Paulo: Saraiva, 2000, p. 138.

${ }_{143}$ BARTELSON, Jens. A genealogy of sovereignty. Cambridge: Cambridge University Press, 1995, p. 189.

${ }^{144}$ FERREIRA, Pinto. Teoria geral do Estado. 3. Ed. São Paulo: Saraiva, 1975, v. 1, p. 207.

${ }^{145}$ MALUF, Sahid. Teoria geral do Estado. 26. Ed. São Paulo: Saraiva, 2003, p. 29.

${ }^{146}$ SPRUYT, Hendrik. The sovereign state and its competitors. Princeton: Princeton university press, 1994, p. 17.

${ }^{147}$ BOBBIO, Norberto; MATTEUCCI, Nicola; PASQUINO, Gianfranco. Dicionário de política. 5. Ed. Brasília: UnB, 2004, v. 2, p. 1179.

${ }^{148}$ KRASNER, Stephen. D. Sovereignty: organized hypocrisy. Princeton: Princeton University Press, 1999, p. 47.

${ }^{149}$ DAILLIER, Patrick; FORTEAU, Mathias; PELLET, Allain. Droit international public. 8. Ed. Paris: LGDJ, 2009, p. 474-478.

${ }^{150}$ ACQUAVIVA, Marcus Cláudio. Teoria Geral do Estado. São Paulo: Saraiva, 1994, p. 46.

${ }^{151}$ LUPI, André Lipp Pinto Basto. Soberania, OMC e Mercosul. São Paulo: Aduaneiras, 2001, p. 41.
} 


\section{REVI STA ELETRÔNI CA DA \\ FACULDADE DE DI REITO DE FRANCA \\ www.revista.direitofranca.br \\ v. 7, n.1, jul/ 2013, I SSN: 1983-4225}

inalienabilidade, a imprescritibilidade, a inviolabilidade e a indelegabilidade ${ }^{152}$. A maioria da doutrina, porém, restringe os atributos da soberania aos seguintes: a unidade, a indivisibilidade, a inalienabilidade e a imprescritibilidade ${ }^{153}$.

Quando se fala em unidade da soberania, o que se quer dizer é que não existe mais de uma soberania no mesmo Estado. De outro lado, a indivisibilidade vem para afirmar que não existem partes separadas do poder soberano. Já a inalienabilidade, significa que aquele ente que perdeu a soberania, desaparece enquanto Estado. Por fim, a imprescritibilidade a pretensão de existência permanente desse atributo.

Já não se fala, porém, em poder absoluto. A soberania é limitada pelo direito natural, pelo direito grupal (grupos particulares que compõem o Estado), bem como pelos imperativos de coexistência pacífica ${ }^{154}$, vale dizer, trata-se de um poder limitado pelo direito ${ }^{155}$. Embora Luigi Ferrajoli ${ }^{156}$ sustente uma antinomia irredutível entre soberania e direito, será utilizada a ideia do direito como limitador da soberania, em especial o direito internacional ${ }^{157}$.

\subsection{CRISE DA SOBERANIA: SUPERAÇÃO OU RECONSTRUÇÃO DO CONCEITO?}

De acordo com a concepção clássica, o Estado soberano "controla a forma, domina a tecnologia e a economia, reconhece apenas instituições iguais”"158. Hoje essa ideia é uma meia verdade.Os limites dos Estados não definem mais os limites dos mercados ${ }^{159}$. Há uma perda do protagonismo na produção normativa, surgem entidades supranacionais, há um aumento dos

${ }^{152}$ MENEZES, Aderson. Teoria Geral do Estado. 2. Ed. Rio de Janeiro: Forense, 1967, p. 151.

${ }^{153}$ BASTOS, Celso Ribeiro. Teoria do Estado e ciência política. 6. Ed. São Paulo: Celso Bastos, 2004, p. 97; STRECK, Lênio Luiz; MORAIS, José Luiz Bolzan de. Ciência política e teoria do Estado. 6. Ed. Porto Alegre: Livraria do advogado, 2008, p. 168; MALUF, Sahid. Teoria geral do Estado. 26. Ed. São Paulo: Saraiva, 2003, p. 33; FERREIRA, Pinto. Teoria geral do Estado. 3. Ed. São Paulo: Saraiva, 1975, v. 1, p. 211; SOARES, Mário Lúcio Quintão. Teoria do Estado: novos paradigmas em face da globalização. 3. Ed. São Paulo: Atlas, 2008, p. 103; DALLARI, Dalmo de Abreu. Teoria geral do Estado. 30. Ed. São Paulo: Saraiva, 2011, p. 87.

${ }^{154}$ MALUF, Sahid. Teoria geral do Estado. 26. Ed. São Paulo: Saraiva, 2003, p. 37.

${ }^{155}$ FERREIRA, Pinto. Teoria geral do Estado. 3. Ed. São Paulo: Saraiva, 1975, v. 1, p. 212.

${ }^{156}$ FERRAJOLI, Luigi. A soberania no mundo moderno. Tradução de Carlo Coccioli e Marcio Lauria Filho. 2. Ed. São Paulo: Martins Fontes, 2007, p. 3.

${ }^{157}$ DAILLIER, Patrick; FORTEAU, Mathias; PELLET, Allain. Droit international public. 8. Ed. Paris: LGDJ, 2009, p. 467.

${ }^{158}$ CASSESE, Sabino. A crise do Estado. Tradução de Ilse Pachoal Moreira e Fernanda Landucci Ortale. Campinas: Saberes, 2010, p. 55.

${ }^{159}$ CASSESE, Sabino. A crise do Estado. Tradução de Ilse Pachoal Moreira e Fernanda Landucci Ortale. Campinas: Saberes, 2010, p. 57. 


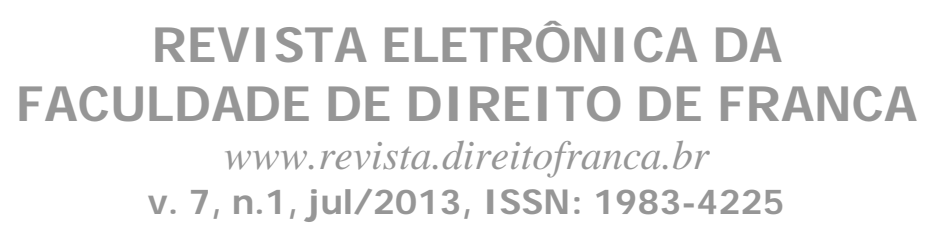

produtores de direito geram a desagregação do Estado ${ }^{160}$. Há uma série de fatores críticos que afetam a concepção clássica de soberania para o mundo atual: a globalização, novas políticas culturais e étnicas, a questão da viabilidade de alguns Estados em razão dos problemas póscoloniais, o tamanho das multinacionais, a revolução da informação e a reconfiguração da economia e do comércio mundial ${ }^{161}$. As noções mais tradicionais como a soberania são“postas em xeque pela diversidade, heterogeneidade e complexidade do processo de transnacionalização dos mercados de insumo, produção, capitais e consumo" ${ }^{\text {"162 }}$.

Três principais críticas são formuladas ao conceito clássico de soberania ${ }^{163}$. Em primeiro lugar, há a alegação de que soberania se opõe a divisões de poder que são possíveis e necessárias para os regimes republicano e democrático. Em segundo lugar, há a noção de que os estados são "moralmente limitados", mas apesar disso continuam, de acordo com o princípio da soberania, sendo o árbitro final de autoridade moral. Em terceiro lugar, há a alegação de que como as fontes de autoridade são inevitavelmente múltiplas, a soberania é sempre limitada, nunca absoluta.

Com efeito, a soberania significou historicamente a negação de toda subordinação ou limitação do poder do Estado por qualquer outro poder ${ }^{164}$, isto é, a soberania seria um poder que não se subordina a nenhum outro. Todavia, a globalização afeta essa ideia de soberania do Estado, na medida em que as decisões de um Estado podem afetar pessoas em outro Estado, e a coincidência entre os participantes da decisão e os afetados é cada vez mais difícil na sociedade mundial interdependente ${ }^{165}$. Em razão disso, há quem sustente que o conceito de soberania deve ser abandonado ou reconfigurado para fazer sentido nessa nova constelação ${ }^{166}$.

De fato, a soberania não pode manter hoje a sua concepção mais clássica. Há muitas forças que desafiam os modelos e práticas estabelecidas por esta concepção clássica do Estado

\footnotetext{
${ }^{160}$ CASSESE, Sabino. A crise do Estado. Tradução de Ilse Pachoal Moreira e Fernanda Landucci Ortale. Campinas: Saberes, 2010, p. 58.

${ }_{161}$ BAKER, Randall. Challenges to traditional concepts of sovereignty. Public Administration and development, $\mathrm{n}^{\circ}$ 20, 2000, p. 2.

${ }^{162}$ FARIA, José Eduardo. O direito na economia globalizada. São Paulo: Malheiros, 2000, p. 23.

${ }^{163}$ DAHBOUR, Omar. Advocating sovereignty in an age of globalization. Journal of social philosophy, Vol. 37 No. 1, Spring 2006, p. 110.

${ }_{164}^{164}$ JELLINEK, Georg. TeoriaGeneral del Estado. Traducción por Fernando de Los Rios Urruti. Granada: Comares, 2000, p. 466.

${ }^{165}$ BAKER, Randall. Challenges to traditional concepts os sovereignty. Public Administration and development, $\mathrm{n}^{\circ}$ 20, 2000, p. 3.

${ }^{166}$ BARTELSON, Jens. The concept of sovereignty revisited. The European Journal of International Law Vol. 17 no.2, 2006, p. 464.
} 


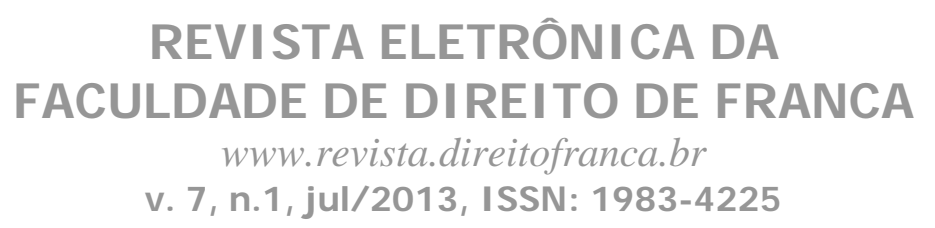

soberano, como a globalização e a internacionalização do direito, o surgimento de novas esferas, como a União Europeia, a reconfiguração do comércio mundial em blocos comerciais gigantescos, o aumento das comunicações aldeia global, a privatização, o regionalismo, o aumento da concentração empresarial, os problemas ambientais globais, e vários outros desafios ${ }^{167}$. Assim, é essencial efetivamente repensar esse conceito e reconfigurá-lo ${ }^{168}$.

A ideia é reconhecer talvez até mais de um tipo de soberania, como fez Stephen D. Krasner ${ }^{169}$, para quem, haveria quatro conceitos de soberania, a saber: soberania internacional jurídica, a soberania westfaliana, a soberania doméstica e a soberania de interdependência. A primeira seria o reconhecimento recíproco entre os Estado, ao passo que a westfaliana representaria a exclusão de exclusão de autoridades externas. De outro lado, a soberania doméstica representaria a organização formal da autoridade e capacidade de exercer o poder dentro das fronteiras. Por fim, a soberania de interdependência envolveria aregulação do fluxo de informações, ideias, bens, pessoas, poluentes e capitais através das fronteiras. O mesmo autor reconhece ainda que os Estados não precisam gozar necessariamente das quatro concepções da soberania.

Em todo caso, asoberania do Estadojánão pode termais a mesma acepção. A transnacionalização e o pluralismo jurídico, no sentido de multiplicidade de atores, arenas, métodos e formas de produção do direito, refletem a necessidade dessa mudança do conceito, na medida em que já não se pode falar em um centro unitário de poder para tomada das decisões e definição das regras jurídicas ${ }^{170}$. O direito não vem mais apenas do Estado, mas também de entidades supranacionais. Cada vez mais outros atores internacionais participam de modo ativo da elaboração de regras. "A crise da unidade dos Estados e a crise de sua soberania econômica

${ }^{167}$ BAKER, Randall. Challenges to traditional concepts of sovereignty. Public Administration and development, $\mathrm{n}^{\circ}$ 20, 2000, p. 1.

${ }^{168}$ DAHBOUR, Omar. Advocating sovereignty in an age of globalization. Journal of social philosophy, Vol. 37 No. 1, Spring 2006, p. 108.

${ }^{169}$ KRASNER, Stephen. D. Sovereignty: organized hypocrisy. Princeton: Princeton University Press, 1999, p. 3-4.

170 RANDERIA, Shalini. Pluralismojurídico, soberania fraturada e direitos de cidadania diferenciais: instituiçõesinternacionais, movimentossociais e Estado pós-colonial na Índia. In: SANTOS, Boaventura de Sousa (org). Reconhecerparalibertar: Os caminhos do cosmopolitismo multicultural. Rio de Janeiro: CivilizaçãoBrasileira, 2003, p. 467-468. 


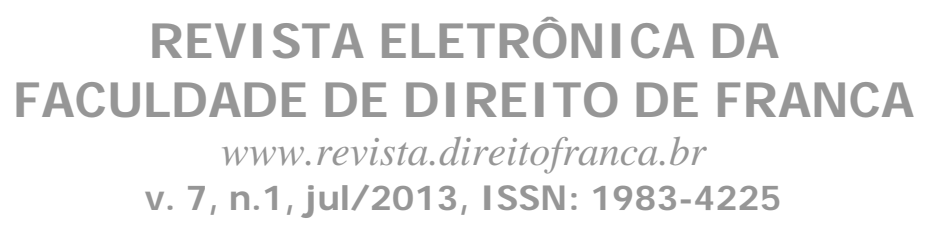

convergem em um resultado único, a constituição de ordens supranacionais organizadas em redes em vez de hierarquias" ${ }^{171}$.

Ademais, surgiram blocos econômicos, militares, "governos “ de âmbito regional, internacional e global que permitem um governar para além das fronteiras. E a participação nesses blocos é medida que acaba se impondo em função das exigências de uma sociedade globalizada. Há a necessidade de cooperação entre autoridades de diferentes países e absorção de competências de organismos estatais por entidades supranacionais ${ }^{172}$.Pode-se afirmar, portanto, que a globalização é um catalisador na mudança do conceito de soberania ${ }^{173}$. "É claro que não se apagam o princípio da soberania nem o Estado-nação, mas são radicalmente abalados em suas prerrogativas" ${ }^{\prime 174}$.

Assim, a globalização também afeta a ideia de soberania do Estado ${ }^{175}$, na medida em que as decisões de um Estado podem afetar pessoas em outros Estados e a coincidência entre os participantes da decisão e os afetados é cada vez mais difícil na sociedade mundial interdependente. Os atributos normalmente colocados como consectários da soberania vêm sendo progressivamente relativizados e enfraquecidos, em especial pelo ganho de poder dos mercados e pelo surgimento de novos atores ${ }^{176}$.

A perpetuidade e a imprescritibilidade da soberania representam hoje a ideia da continuidade no tempo e não mais sua perenidade, em todo caso limitado pelo princípio da eficácia nas relações internacionais ${ }^{177}$. Já há algum tempo não se admite mais o absolutismo na soberania que está sujeita ao menos a limites jurídicos, impostos especialmente pelo direito internacional. A soberania é relativa, limitada no tempo pelo princípio da eficácia e

\footnotetext{
${ }^{171}$ CASSESE, Sabino. A crise do Estado. Tradução de Ilse Pachoal Moreira e Fernanda Landucci Ortale. Campinas: Saberes, 2010, p. 31.

${ }^{172}$ CASSESE, Sabino. A crise do Estado. Tradução de Ilse Pachoal Moreira e Fernanda Landucci Ortale. Campinas: Saberes, 2010, p. 41.

${ }_{173}^{173}$ ROCHA, Luiz Alberto G. S. Estado, democracia e globalização. Rio de Janeiro: Forense, 2008, p. 80.

${ }^{174}$ FARIA, José Eduardo. O direito na economia globalizada. São Paulo: Malheiros, 2000, p. 24.

${ }^{175}$ BOGDANDY, A. V. e DELLAVALLE, S. Universalism and particularism as paradigms of international law.IILJ WorkingPaper 2008/3, p. 20.

${ }^{176}$ FARIA, José Eduardo. Direito e conjuntura. 2. Ed. São Paulo: Saraiva, 2010, p. 37.

${ }^{177}$ LUPI, André Lipp Pinto Basto. Soberania, OMC e Mercosul. São Paulo: Aduaneiras, 2001, p. 275.
} 


\section{REVI STA ELETRÔNI CA DA \\ FACULDADE DE DI REITO DE FRANCA \\ www.revista.direitofranca.br \\ v. 7, n.1, jul/ 2013, I SSN: 1983-4225}

possivelmente divisível ${ }^{178}$. Há que se admitir ao menos, a delegação, a transmissão de parcelas do seu exercício como na OMC e no MERCOSUL ${ }^{179}$.

É certo que deve-se ir da soberania absoluta para a soberania compartilhada ${ }^{180}$.Todos concordam que o conceito tradicional de soberania é inadequado para capturar a complexidade das relações internacionais contemporâneas. Hoje, deve-se falar em conexão e não em separação, em interação e não emisolamento. A nova soberania é a conexão com o resto do mundo e a habilidade política para ser um ator dentro dela ${ }^{181}$. A soberania deve ser relacional, no sentido de descrever a capacidade de se engajar e não a capacidade de resistir. Trata-se de um conceito que vai se adaptar a futuras circunstâncias dentro da sociedade internacional ${ }^{182}$.

Globalização e soberania não precisam ser apresentadas em termos antagônicos, uma vez que a globalização não precisa acabar com a soberania, mas deve apenas impor novas conformações desse conceito. A globalização não é a diminuição da soberania do Estado (habilidade de lidar com seus próprios negócios), mas fundamentalmente é a reconstrução da soberania com a remodelação do Estado ${ }^{183}$. Há, sem dúvida, um processo de internacionalização do Estado com sua participação em organizações internacionais sendo cada vez mais relevante, como na Organização Mundial do Comércio - OMC, vale dizer, há uma redução da liberdade com a transferência de poderes para outros entes ${ }^{184}$. Os estados individuais já não têm a suprema autoridade para fazerregras internas sobre todas as questões ${ }^{185}$. Os grandes regimes multilaterais do mundo pós-Guerra Fria, a crescente importância e influênciadas empresas multinacionais e as ONG's, o crescimento das finanças e comércio internacionais, encorajam os Estados a entregar alguns dos seus poderes.

\footnotetext{
${ }^{178}$ LUPI, André Lipp Pinto Basto. Soberania, OMC e Mercosul. São Paulo: Aduaneiras, 2001, p. 319.

${ }^{179}$ LUPI, André Lipp Pinto Basto. Soberania, OMC e Mercosul. São Paulo: Aduaneiras, 2001, p. 285.

${ }^{180}$ DELMAS-MARTY, Mireille.La refoundation des pouvoirs. Paris: Seuil, 2007, p. 265; AUBY, Jean-Bernard. La globalization, le droitetl'État. 2. Ed. Paris: LGDJ, 2010, p. 145.

${ }^{181}$ SLAUGHTER, Anne-Marie. A New World order. Princeton: Princeton University Press, 2004, p. 267.

182 FOWLER, Michael Ross; BUNCK, Julie Marie. Law, power and the sovereign state: the evolution and application of the concept of sovereignty. Penn State Press, 1995, p. 163.

${ }^{183}$ CLARK, Ian. Globalization and international relations theory. New York: Oxford, 1999, p. 79-80; LUPI, André Lipp Pinto Basto. Soberania, OMC e Mercosul. São Paulo: Aduaneiras, 2001, p. 259.

${ }_{184}$ TANZI, Vito, The Demise of the Nation State? (August 1998). IMF Working Paper, Vol. , pp. 1-17, 1998. Available at SSRN: http://ssrn.com/abstract=882660. Acesso em 15/02/2011.

${ }^{185}$ ENGLEHART, N. A. , 2006-04-20. The Fragmentation of Sovereignty: Globalization and the Persistence of States" Paper presented at the annual meeting of the The Midwest Political Science Association, Palmer House Hilton, $\quad$ Chicago, IllinoisOnline $\quad<\mathrm{PDF}>$. $2011-03-14$ from http://www.allacademic.com/meta/p139887_index.html.Acesso em 18/03/2011.
} 


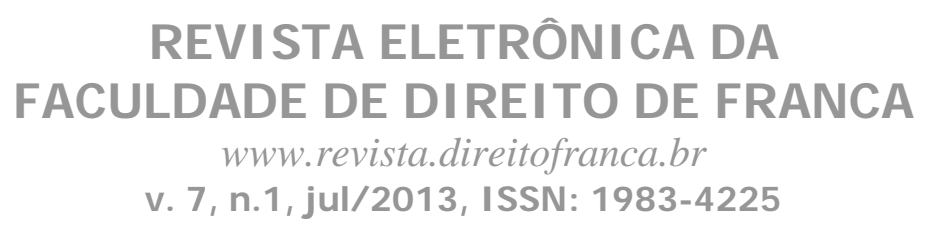

Todavia, é fundamentalressaltarquenão se pretende acabarcom a ideia de soberania do Estado. O Estado mantém suasoberania, mas responde a novasnecessidades de participação e coordenação ${ }^{186}$. A Soberania como independência, com caráter formal, enquanto ausência de subordinação a outro Estado, mantém intacta no Brasil. De outro lado, a soberania como autonomia, isto é, como liberdade dentro de um quadro de competência está mais limitada pela própria inserção brasileira no cenário global ${ }^{187}$, especialmente na OMC e no MERCOSUL. A realidade atual e o futuro exigem uma soberania inclusiva e cooperativa ${ }^{188}$.

\section{CONCLUSÃO}

O mundo tem mudado bastante com a nova realidade imposta pela globalização econômica e, não poderia ser diferente. A nova realidade imposta por esse fenômeno exige mudanças em vários da realidade atual, inclusive no que As concepções clássicas do Estado Nacional, da produção normativa e da própria soberania precisam se adaptar a nova realidade, sem, contudo desaparecer. O catalisador dessas mudanças é indubitavelmente a globalização econômica que, independentemente dos problemas que traz consigo, é realidade que impacta a sociedade, os Estados Nacionais, o próprio direito e a soberania.

A atual realidade social e econômica não pode se conformar com regras exclusivamente nacionais, pois os fluxos de informações, pessoas, capitais e mercadorias romperam com as fronteiras dos antigos estados nacionais. Um direito exclusivamente nacional é um direito parcial, vale dizer, são essenciais regras internacionais ao lado das regras nacionais. Há, portanto, a necessidade de uma internacionalização do direito, ainda que em fragmentos e em tempos diferenciados. Apesar de eventuais críticas, a nova realidade mundial forjada pela globalização econômica é a responsável pelo surgimento desse tipo de direito, cuja aplicação representa o

186 ALBERTON, Genacéia da Silva. Tribunalização e jurisprudencialização do EstadoContemporâneo; perspectivapara o Mercosul. Revista dos Tribunais, ano 91, volume 800, junho de 2002, p. 16; RANDERIA, Shalini. Pluralismojurídico, soberania fraturada e direitos de cidadania diferenciais: instituiçõesinternacionais, movimentossociais e Estado pós-colonial na Índia. In: SANTOS, Boaventura de Sousa (org). Reconhecerparalibertar: Os caminhos do cosmopolitismo multicultural. Rio de Janeiro: CivilizaçãoBrasileira, 2003, p. 468.

${ }^{187}$ LUPI, André Lipp Pinto Basto. Soberania, OMC e Mercosul. São Paulo: Aduaneiras, 2001, p. 320.

${ }^{188}$ AUBY, Jean-Bernard.La globalization, le droitetl'État. 2. Ed. Paris: LGDJ, 2010, p. 145. 


\section{REVI STA ELETRÔNI CA DA \\ FACULDADE DE DIREITO DE FRANCA \\ www.revista.direitofranca.br \\ v. 7, n.1, jul/ 2013, I SSN: 1983-4225}

triunfo de um pluralismo jurídico inerente à complexidade das relações que se instauram na órbita econômica.

Um Estado nacional com sua configuração clássica também não consegue exercer suas funções do mesmo modo. Os elementos clássicos e as funções clássicas dos Estados não podem se manter. Novas realidades exigem cada vez mais integração em níveis globais ou até supranacionais. Não se adequar a essas exigências significará necessariamente uma ineficiência da atual estatal.

Do mesmo modo, a soberania já não pode ter mais a mesma concepção clássica. Não se pode mais falar em uma soberania absoluta, embora esse atributo sempre tenha sido discutível. Mas, especialmente não se pode mais falar em uma soberania indivisível. Deve-se ir da soberania absoluta para a soberania compartilhada. Todos concordam que o conceito tradicional de soberania é inadequado para capturar a complexidade das relações internacionais contemporâneas. As palavras chaves são conexão e interação e não separação e isolamento. A nova soberania é a conexão com o resto do mundo e a habilidade política para ser um ator dentro dela.

\section{REFERÊNCIAS BIBLIOGRÁFICAS}

ACQUAVIVA, Marcus Cláudio. Teoria Geral do Estado. São Paulo: Saraiva, 1994.

ALBERTON, Genacéia da Silva. Tribunalização e jurisprudencialização do EstadoContemporâneo; perspectivapara o Mercosul. Revista dos Tribunais, ano 91, volume 800, p. 11-35, junho de 2002.

ALMEIDA, Paulo Roberto de. O Brasil e o multilateralismo econômico. PortoAlegre: Livraria do Advogado, 1999.

ARNOLD, Rainer. Alcune riflessioni sulla nozione e sugli effetti dela globalizzazione. In: AMATO, Cristina; PONZANELLI, Giulio (a cura di). Global law v. local law: problemi dela globalizzazione giuridica. Torino: Giappichelli, 2006, p. 3-5.

ARRIGHI, Giovanni. O longoséculo XX. Tradução de VeraRibeiro. Rio de Janeiro: Contraponto, 1996.

AUBY, Jean-Bernard. La globalization, le droitetl'État. 2. Ed. Paris: LGDJ, 2010.

AZAMBUJA, Darcy. Teoria geral do Estado. 4. Ed. São Paulo: Globo, 2008. 


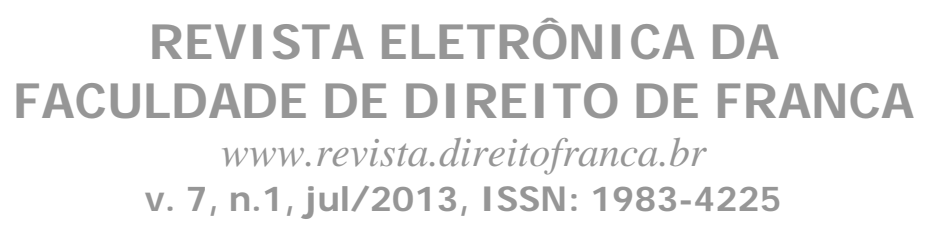

BAKER, Randall. Challenges to traditional concepts of sovereignty.Public Administration and development, $\mathrm{n}^{\circ}$ 20, p. 1-15, 2000.

BARTELSON, Jens. The concept of sovereignty revisited. The European Journal of International Law Vol. 17 no.2, p. 463-474, 2006. A genealogy of sovereignty. Cambridge: Cambridge University Press, 1995.

BASTOS, Celso Ribeiro. Teoria do Estado e ciência política. 6. Ed. São Paulo: Celso Bastos, 2004.

BECK, Ulrich. O que é a globalização?Tradução de André Carone. São Paulo: Paz e Terra, 1999.

BHAGWATI, Jagdish. Emdefesa da globalização. Tradução de Regina Lyra. Rio de Janeiro: Elsevier, 2004.

BOBBIO, Norberto. Liberalismo e democracia. Tradução de Marco Aurélio Nogueira. São Paulo: Brasiliense, 2005.

; MATTEUCCI, Nicola; PASQUINO, Gianfranco. Dicionário de política. 5. Ed. Brasília: UnB, 2004, 2 v.

BODIN, Jean. Os seis livros da República: livro primeiro. Tradução de José Ignácio Coelho Mendes Neto. São Paulo: Ícone, 2011.

BOGDANDY, A. V. e DELLAVALLE, S. Universalism and particularism as paradigms of international law.IILJWorking Paper 2008/3, 64 p.

BONAGLIA, Federico; GOLDSTEIN, Andrea. Globalizzazione e sviluppo. 2. Ed. Bologna: Il mulino, 2008.

BONAVIDES, Paulo. Ciência política. 10. Ed. São Paulo: Malheiros, 1994.

BROWNLIE, Ian. Principles of international law. 7. Ed. Oxford: Oxford, 2008.

BURDEAU, Georges. O Estado. Tradução de Maria Ermantina de Almeida Prado Galvão. São Paulo: Martins Fontes, 2005.

CALMON, Pedro. Curso de Teoria Geral do Estado. Rio de Janeiro: Freitas Bastos, 1958.

CASSESE, Antonio. International law. 2. Ed. Oxford: Oxford, 2005.

CASSESE, Sabino. A crise do Estado. Tradução de Ilse Pachoal Moreira e Fernanda Landucci Ortale. Campinas: Saberes, 2010. 


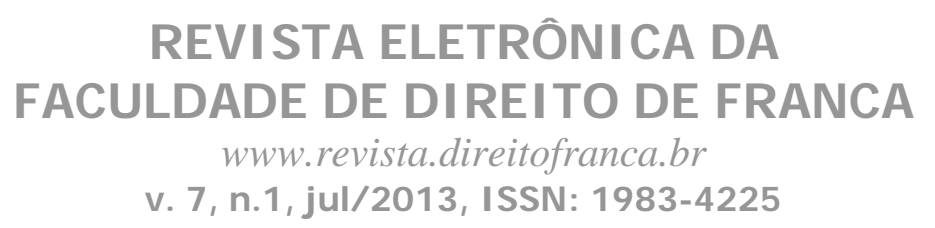

CHEVAlliER, Jacques. O Estado pós-moderno. Tradução de Marçal Justen Filho. Belo Horizonte: Fórum, 2009.

CLARK, Ian. Globalization and international relations theory. New York: Oxford, 1999.

CREVELD, Martin van.Ascensão e declínio do Estado. Tradução de Jussara Simões. São Paulo: Martins Fontes, 2004.

DAHBOUR, Omar. Advocating sovereignty in an age of globalization.Journal of social philosophy, Vol. 37 No. 1, p. 108-126, Spring 2006.

DAILLIER, Patrick; FORTEAU, Mathias; PELLET, Allain.Droit international public. 8. Ed. Paris: LGDJ, 2009.

DALLARI, Dalmo de Abreu. Teoria geral do Estado. 30. Ed. São Paulo: Saraiva, 2011.

DE LEO, Walter N. Derecho de los negocios en el comercio. Buenos Aires: Universidad, 1999.

DELMAS-MARTY, Mireille. La refoundation des pouvoirs. Paris: Seuil, 2007.

DEZALAY, Ives; TRUBEK, David M. A reestruturação global e o direito: a internacionalização dos campos jurídicos e a criação de espaços transacionais. In: FARIA, José Eduardo (org.). Direito e globalização econômica. São Paulo: Malheiros, 1996.

DUGUIT, León. Law in the modern state.Translated by Frida and Harold Laski. New York: Huebsch, 1919.

ELCIN, Mert. The applicable Law to international commercial contracts and status of lex mercatoria. Boca Raton: Dissertation.com, 2010.

ENGLEHART, N. A. 2006-04-20.The Fragmentation of Sovereignty: Globalization and the Persistence of States" Paper presented at the annual meeting of the The Midwest Political Science Association, Palmer House Hilton, Chicago, IllinoisOnline <PDF>. 2011-03-14 from http://www.allacademic.com/meta/p139887_index.html.Acesso em 18/03/2011.

FALCÃO, Maurin Almeida. Livre-comércio: quecontextopolítico? Aspectoshistóricos das dificuldades dos paísesemdesenvolvimentoouemtransição, no acesso a mercados. Revista do Programa de MestradoemDireito do UniCEUB, Brasília,v. 2, n. 2, p. 1-11, jul./dez. 2005.

FARIA, José Eduardo. Direito e conjuntura. 2. Ed. São Paulo: Saraiva, 2010. . O direito na economia globalizada. São Paulo: Malheiros, 2000.

FAZIO, Silvia. The harmonization of international commercial law.AlphenaandenRijn: Kluwer Law International, 2007. 


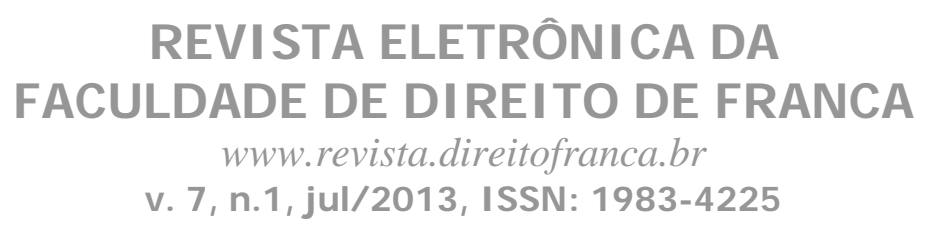

FERRAJOLI, Luigi. A soberania no mundo moderno. Tradução de Carlo Coccioli e Marcio Lauria Filho. 2. Ed. São Paulo: Martins Fontes, 2007.

FERREIRA, Pinto. Teoria geral do Estado. 3. Ed. São Paulo: Saraiva, 1975, v. 1.

FILOMENO, José Geraldo. Manual de teoria geral do Estado. 7. Ed. Rio de Janeiro: Forense universitária, 2009.

FLEINER-GESTER, Tomas. Teoria geral do Estado. Tradução de Marlene Holzhausen. São Paulo: Martins Fontes, 2006.

FOWLER, Michael Ross; BUNCK, Julie Marie.Law, power and the sovereign state: the evolution and application of the concept of sovereignty. Penn State Press, 1995.

GALGANO, Francesco. História do Direitocomercial. Tradução de João Espírito Santo. Lisboa: PF, 1990.

. La globalizzazione nello spechio del diritto. Bologna: Il Mulino, 2005.

GRAU, Eros Roberto. A ordemeconômica na Constituição de 1988. 3. ed.São Paulo: Malheiros, 1997.

HABERMAS, Jürgen. A constelação pós-nacional: ensaios políticos. Tradução de Márcio Seligmann- Silva. São Paulo: Littera Mundi, 2001.

HELLER, Herman. La sovranitáedaltriscrittisulladottrinadeldiritto e dellostato. Milano: Giuffrè, 1987.

HOBSBAWM, Eric. A era dos extremos: o breveséculo XX (1914 - 1991). Tradução de Marcos Santarrita. São Paulo: Companhia das Letras, 1995.

IUDICA, Giovanni. Law \& globalization. Revista de direito bancário e do mercado de capitais. São Paulo, ano13, n.47, p. 173-199, jan-mar 2010.

JELLINEK, Georg. TeoriaGeneraldelEstado. Traducción por Fernando de Los Rios Urruti. Granada: Comares, 2000.

KELSEN, Hans. Teoria geral do direito e do Estado. 2. Ed. São Paulo: Martins Fontes, 1992.

KRASNER, Stephen. D. Sovereignty: organized hypocrisy. Princeton: Princeton University Press, 1999.

KRIELE, Martin. Introdução à teoria do Estado: os fundamentos históricos da legitimidade do Estado Constitucional Democrático. Tradução de Urbano Carvelli. Porto Alegre: Sergio Antonio Fabris, 2008. 


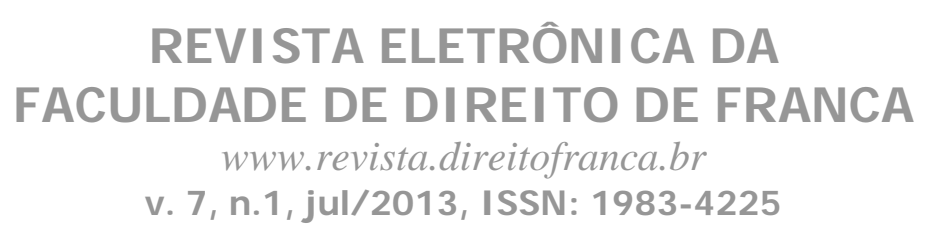

LUPI, André Lipp Pinto Basto. Soberania, OMC e Mercosul. São Paulo: Aduaneiras, 2001.

MALUF, Sahid. Teoria geral do Estado. 26. Ed. São Paulo: Saraiva, 2003.

MENDONÇA, Jacy de Souza. O homem e o Estado. São Paulo: Rideel, 2010.

MENEZES, Aderson. Teoria Geral do Estado. 2. Ed. Rio de Janeiro: Forense, 1967.

MICHAELS, Ralf. The true lex mercatoria: law beyond the state. Indiana Journal of Global Legal Studies Vol. 14 \#2, p. 447-468, Summer 2007.

NASSER, Rabih Ali. A liberalização do comérciointernacional nas normas do GATT- OMC. São Paulo: Ltr, 1999.

NUSDEO, Ana Maria de Oliveira. Defesa da concorrência e globalizaçãoeconômica: o controle da concentração de empresas. São Paulo: Malheiros, 2002.

PETRELLA, Ricardo. Globalization and internationalization: the dynamics of the emerging world order. In: BOYER, Robert; DRACHE, Daniel (ed.). States against markets. London: Routledge, 1996.

POLANYI, Karl. A grande transformação. 9. ed.Tradução de Fanny Wrobel. Rio de Janeiro: Elsevier, 2000.

RANDERIA, Shalini. Pluralismojurídico, soberaniafraturada e direitos de cidadania diferenciais: instituiçõesinternacionais, movimentossociais e Estado pós-colonial na Índia. In: SANTOS, Boaventura de Sousa (org). Reconhecerparalibertar: Os caminhos do cosmopolitismo multicultural. Rio de Janeiro: Civilização Brasileira, 2003.

REALE, Miguel. Teoria do Direito e do Estado. 5. Ed. São Paulo: Saraiva, 2000.

ROCHA, Luiz Alberto G. S. Estado, democracia e globalização. Rio de Janeiro: Forense, 2008.

ROTH, André- Noël. O direito em crise: Fim do Estado moderno? In: FARIA, José Eduardo (org.). Direito e globalização econômica. São Paulo: Malheiros, 1996.

SANTOS, Boaventura de Sousa. Por uma concepção multicultural de direitoshumanos. In:

(org). Reconhecerparalibertar: os caminhos do cosmopolitismo multicultural. Rio de Janeiro: CivilizaçãoBrasileira, 2003.

SHAW, Malcom N. International law. 6. Ed. Cambridge: Cambridge, 2008.

SLAUGHTER, Anne-Marie.A New World order.Princeton: Princeton University Press, 2004.

SOARES, Mário Lúcio Quintão. Teoria do Estado: novos paradigmas em face da globalização. 3. Ed. São Paulo: Atlas, 2008. 